\title{
Product Liability and Product Safety in a Federal System: Economic Reflections on the Proper Role of Europe
}

Citation for published version (APA):

Faure, M. G. (2002). Product Liability and Product Safety in a Federal System: Economic Reflections on the Proper Role of Europe. In Marciano A., \& Josselin J.M. (Eds.), The Economics of Harmonizing European Law (pp. 131-177). Edward Elgar Publishing. https://doi.org/10.4337/9781781950692.00016

Document status and date:

Published: 01/01/2002

DOI:

10.4337/9781781950692.00016

Document Version:

Publisher's PDF, also known as Version of record

\section{Please check the document version of this publication:}

- A submitted manuscript is the version of the article upon submission and before peer-review. There can be important differences between the submitted version and the official published version of record.

People interested in the research are advised to contact the author for the final version of the publication, or visit the DOI to the publisher's website.

- The final author version and the galley proof are versions of the publication after peer review.

- The final published version features the final layout of the paper including the volume, issue and page numbers.

Link to publication

\footnotetext{
General rights rights.

- You may freely distribute the URL identifying the publication in the public portal. please follow below link for the End User Agreement:

www.umlib.nl/taverne-license

Take down policy

If you believe that this document breaches copyright please contact us at:

repository@maastrichtuniversity.nl

providing details and we will investigate your claim.
}

Copyright and moral rights for the publications made accessible in the public portal are retained by the authors and/or other copyright owners and it is a condition of accessing publications that users recognise and abide by the legal requirements associated with these

- Users may download and print one copy of any publication from the public portal for the purpose of private study or research.

- You may not further distribute the material or use it for any profit-making activity or commercial gain

If the publication is distributed under the terms of Article $25 \mathrm{fa}$ of the Dutch Copyright Act, indicated by the "Taverne" license above, 


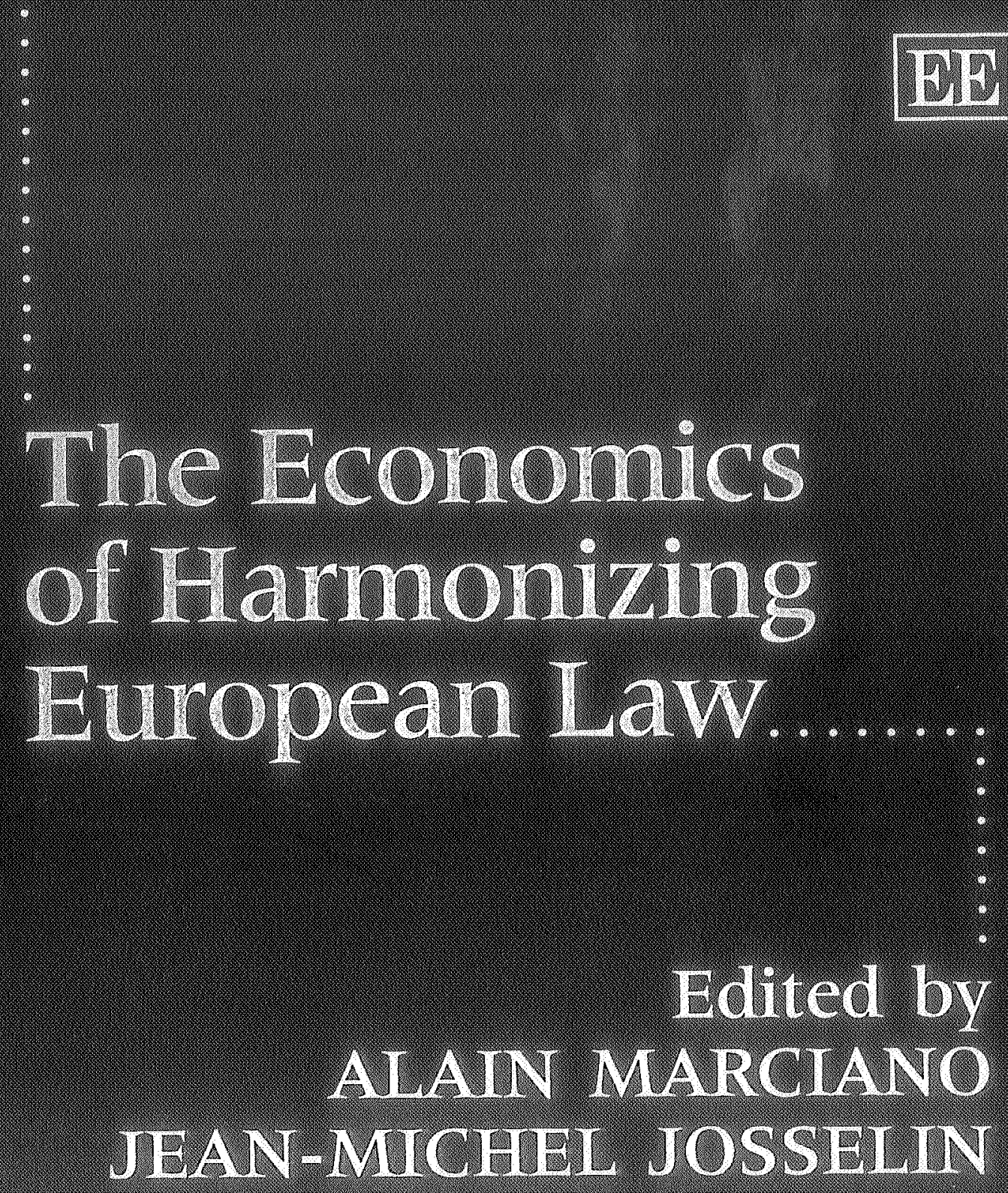

\section{ALAIN MARCIANO} JEAN-MICHEL JOSSELIN

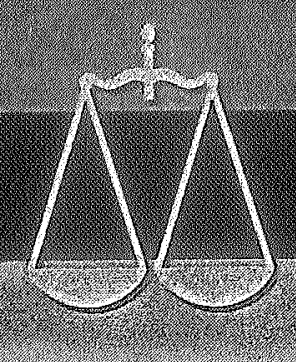

New Horizons in Law and Economics. 

Surveys, 11, 267-95.

Garoupa, N. (1997b), 'Optimal law enforcement and the economics of the drug market: some comments on the Schengen Agreements', International Review of Law and Economics, 17, 521-35.

Harel, A. and U. Segal (1999), 'Criminal law and behavioral law and economics: observations on the neglected role of uncertainty in deterring crime', American Law and Economics Review, 1, 276-312.

Instefjord, N., P. Jackson and W. Perraudin (1998), 'Securities fraud', Economic Policy, 27, 587-603.

Jolls, C., C. Sunstein and R. Thaler (1998), 'A behavioral approach to law and economics', Stanford Law Review, 50, 1471-550.

Kaplow, L. and S. Shavell (2001), 'Any non-welfarist method of policy assessment violates the Pareto Principle', Journal of Political Economy, 109, 281-6.

Polinsky, A.M. and S. Shavell (2000a), 'The fairness of sanctions: some implications for optimal enforcement policy', American Law and Economics Review, 2, 223-7.

Polinsky, A.M. and S. Shavell (2000b), 'The economic theory of public enforcement of law', Journal of Economic Literature, 38, 45-76.

Posner, R.A. (1998), Economic Analysis of Law, Sth edition, New York: Aspen Law \& Business.

Prinz, A. (1997), 'Do European drugs policies matlcr?, Economic Policy, 25, 37.3-85.

\section{Product liability and product safety in a federal system: economic reflections on the proper role of Europe}

\section{Michael G. Faure}

\subsection{INTRODUCTION}

In Europe it has been known for a long time that the domains of product safety and product liability are, for many years now, no longer subjected to only national legislation. Europe has issued many Directives harmonizing product safety standards. In addition there is the Council Directive $85 / 374 /$ EEC of 25 July 1985 on the approximation of the laws, regulations and administrative provisions of the Member States concerning liability for defective products.

The question that will be addressed in this chapter is whether there are economic reasons for a harmonization of product safety standards and product liability. The fact that product safety standards have, to a large extent, been harmonized, can at first blush easily be understood as an important instrument to facilitate interstate trade. However, it is less clear why a harmonization of product liability law was also needed. This harmonization of product liability is all the more remarkable since Europe has so far taken in fact only one initiative with respect to tort law, which is precisely the domain of product liability. Other attempts, for example, to harmonize the liability for services, have failed (see Faure and Hartlief, 1996, pp. 241-2).

The European product liability Directive entered into force when there was not yet any talk about a subsidiarity principle. According to this principle, which was introduced by the Single European Act for environmental matters and enlarged to a general principle of community policy by the Maastricht Treaty, the "community shall take action if and only in so far as the objectives of the proposed action cannot be sufficiently achieved by the Member States and can, therefore, by reason of the scale or effects of the proposed action, be better achieved by the community.'

The issue which will therefore be addressed in this chapter fits, from a legal perspective, in the discussion concerning the interpretation of the subsidiarity principle. This subsidiarity principle indeed allows for a new and probably 
more critical approach concerning the proper role of Europe with respect to product liability. The question arises what reasons can be advanced for a ful harmonization of product liability law. To answer this question, attention will be paid to the economic literature on the optimal level of regulation within federal systems.

It is, moreover, not only academically interesting to address the optimal level of regulation of product liability in Europe. The European Commission itself has also established that the product liability Directive in its current version is not able to reach the goal of harmonizing marketing conditions, which it is, according to the preamble, supposed to achieve. Therefore, on 28 July 1999 a green paper on liability for defective products was launched in which the Commission addressed several features of the product liability Directive which may be reconsidered. One of these issues, although this is only briefly addressed in the green paper, may be the question on the proper division of tasks between Europe and the Member States concerning the regulation of product liability (COM (1999) 396 final).

The chapter is set up as follows: after this introduction the economics of product liability will be summarized in Section 7.2. This seems necessary to be able to provide an adequate judgement of the product liability Directive and the proposals for reform. Then, the European product liability and product safety Directives will be briefly introduced in Section 7.3, to turn immediately to the corpus of the chapter, being the criteria for centralization of product liability and product safety (Section 7.4). In the light of these criteria the question will be asked whether the product liability Directive could effectively reach the goals set and can be considered to promote economic efficiency (Section 7.5). A public choice perspective is presented to explain some of the 'defects' of the product liability Directive (Section 7.6). Finally, a few recent developments will be discussed in Section 7.7 and a few concluding remarks are formulated in Section 7.8 .

\subsection{ECONOMICS OF PRODUCT LIABILITY: AN INTRODUCTION}

It seems useful to start with a brief summary of the economic literature on product liability, ${ }^{2}$ since this will provide us a framework to test the efficiency of the European Directive.

\subsubsection{The Economic Theory of Product Liability}

In the economic literature attention has mostly been paid to the question of how the law can give incentives to producers to induce them on the one hand to spend efficient care on the products they manufacture and on the other hand to produce a sufficient number of products. Indeed, if too many products were to be put on the market, the risk of a product accident could also be increased. The relevant question then is whether the law should set rules to induce parties to reach these efficient care and production levels. And if it were found that a legal intervention is necessary the next question arises whether these efficient levels could best be reached through a fault rule or through a strict liability rule.

\section{Coasean bargaining}

The starting point is the Coase theorem (1960). The first publications on economic analysis of product liability applied the Coase theorem to product liability (McKean, 1970a, 1970b; Buchanan, 1970; and especially Oi, 1973). They showed that in a zero transaction-cost setting the choice of the liability rule will have no effect on the care taken by the producer, nor on the quantity of products put on the market. The well-informed consumer will always base his purchase decision on the full price of the product, being the cost price, increased with the expected accident costs. ${ }^{3}$ As long as the conditions for the Coase theorem are met, both an efficient output and efficient care will follow, irrespective of the legal rule applied (no liability, negligence or strict liability). It is important too that under these conditions the choice of the legal rule also has no distributional consequences (Hamada, 1976). Indeed in a Coasean setting choosing a strict liability rule, for example to 'protect' the consumer, seems meaningless, since the expected accident costs will then still be passed on to the consumer through the price system. Therefore, in these circumstances, legal intervention does not seem very useful. On the contrary: if consumer groups are not homogeneous, but the expected accident costs differ for every consumer ${ }^{4}$ the introduction of a strict liability rule might have adverse effects, since safer products might disappear from the market. ${ }^{5}$ The reason is that the producer does not known which are the consumers with highexpected accident costs. He will therefore set the quality (care) standard at the level of an average consumer and safer products will disappear from the market. ${ }^{6}$ These problems caused by heterogeneous consumer groups have often been advanced as an argument against strict liability.

\section{Stric liability for 'full internalization'}

The papers using the Coase theorem to analyse product liability were subjected to criticism, since it was held that the theorem does not help since the conditions will almost never be fulfilled in a product liability setting. One argument often heard in this respect is that the consumer has no information with respect to the accident risk. ${ }^{7}$ Although consumers can indeed be poorly informed with respect to some risks, ${ }^{8}$ this is certainly not true for all risks. The 
consumer might be well aware of the risks of, for example, a lawn mower. In addition, it should be mentioned that often information could be provided through legislative measures. If these were successful, the conditions for the Coase theorem could again be met. Only if a consumer underestimates the accident risk and the information deficiency cannot be cured through regulation or otherwise, should a liability rule induce the producer to spend enough care on the safety of his products. If consumers remain uninformed non-liability will certainly not lead to an efficient result since producers will have no incentive to invest in safety equipment if this benefit (reduction of expected accident costs) is not recognized by the consumer. It is generally held that a fault rule can induce the producer in such a case to take efficient care, but only a strict liability rule will also lead to an optimal output of products. In this respect strict liability is considered to be a good remedy for underestimation of the risk by consumers. ${ }^{9}$

The latter conclusion is also true when harm is caused to third parties, for example bystanders, who have no connection at all with the producer. A Coasean solution is of course excluded under these circumstances since the transaction costs will be prohibitive. There is also no 'contact' between a producer and third parties through the price mechanism (see Hamada, 1976; Veljanovski, 1981, p. 131). Again, a fault rule would induce the producer to take efficient care, but consumers would purchase too many products. Therefore, the market price would be too low, since it would not reflect the expected accident costs and, given this demand, a too large output of products will follow (see Polinsky, 1983, p. 103 and Shavell, 1987, pp. 49-50). This inefficiency can, again, only be remedied by the introduction of a strict liability rule. Since under such a rule the market price will reflect the expected accident costs, both efficient care will be taken by the producer and an efficient quantity will be produced (Shavell, 1980, p. 3).

Up to this point we have shown that economic theory does not jump to hasty general conclusions with respect to the desirability of a fault or a stric liability rule. Such an answer depends on whether the victim is a consumer or a third party and if it is a consumer a further distinction is made depending on whether or not the consumer underestimates the risk of a product accident However, if consumers do underestimate the risk, or if the harm is caused to third parties, the literature clearly points to the advantages of strict liability from an efficiency viewpoint. These are mostly referred to as the full internalization of the harm through the strict liability rule. However, the economic theory does not stop here. Until now it was assumed that the behaviour of the victim had no influence on the accident risk, that both producers and consumers were risk-neutral and that the market was perfectly competitive The literature has, however, shown that when these assumptions are relaxed the advantage of strict liability, expressed earlier, does not prevail any longer.
Victim's care

It has been stressed that in a bilateral accident situation where the victim also influences the accident risks, liability rules should also give victims an incentive to take appropriate care and not to engage too often in dangerous activities. If the victim has an important influence on the accident risk most authors hold that a fault rule will be preferred to a strict liability rule, even if the latter is combined with a contributory negligence defence. One of the reasons given is the unwillingness of courts to consider the contributory negligence of victims, which might easily affect their incentives. In addition, only a fault rule will lead to an efficient activity level by the victim. It is therefore held that if the victim has an important influence on the accident risk and it is thus more important to control his activity level than it is to control the injuries, a fault rule will be preferred. ${ }^{10}$

\section{Market power}

It has also been pointed out by Polinsky and Rogerson (1983) that a strict liability rule might be problematic in the case where the producer has market power and consumers underestimate the risk of a product accident. When producers have market power, market prices will be relatively high, which will lead to too little demand for the product. This process is increased in the case of strict liability. Then the market price will still be higher than the full price of the product (cost price + expected accident costs). Under a fault rule the market price will be lower since the expected accident costs are not calculated into it. The basic idea of Polinsky and Rogerson is that when consumers underestimate the risk and producers have market power a fault rule might be preferable. The reason is that under a fault rule the market price will be lower and since the consumers underestimate the risk they will not take the expected accident costs into account in their buying decision. Thus demand will increase. Therefore, they argue that with a fault rule one can make use of the underestimation of the accident risk by consumers to fight the natural tenclency of the monopolist to limit the output. So the surprising conclusion is that when the producer has market power he should almost be 'rewarded' for it by introducing a fault rule. Thus it can be avoided that the monopolist reduces the output and that an inefficiently limited number of products is brought on the market. ${ }^{11}$

\section{Attitudes toward risk and insurance}

Finally it should also be mentioned that until now risk neutrality of all the market participants was assumed. If one introduces risk, one could examine whether producers or consumers are risk-averse and allocate the liability accordingly, given the insurance function of a strict liability rule for victims. ${ }^{12}$ This is, however, not very useful, since it is often difficult for the regulator to 
examine the attitude toward risk of all parties involved $e x$ ante. In addition, consumers must be averse to some risks but not to others. Moreover, producers also might be averse to the risks of, for example, serial damage. Therefore it is hard to draw conclusions on the attitude toward risk with respect to the desirability of a certain liability rule.

In addition one would only have to take the insurance (compensatory) function of liability rules into account for risks for which no commercial insurance coverage can be found on the market. In practice both producers and consumers can insure the product risk. In this respect there is, however, an important difference between various types of insurance, which follow from different liability rules. Under a strict liability rule producers will always have to pay compensation. When they are risk-averse, they will purchase third party liability insurance. Victims will always be compensated through the strict liability rule so, irrespective of their attitude toward risk, they would have no demand for insurance. Under a fault rule rational producers will have an incentive to take due care to avoid liability. Since producers will not be found liable consumers will not be compensated through liability rules and risk-averse consumers might purchase first party insurance (see Polinsky, 1983, pp. 100-101)

There is, however, an important difference between both insurance schemes when it comes to the question whether the adverse selection problem can be cured. Under first party insurance the victim himself knows exactly whether he poses a high or a low risk and what type of insurance coverage he needs. Given the different preferences for different types of insurance coverage a narrowing into small-risk pools by the insurer is possible and the adverse selection problem can be avoided. This is not the case in third party insurance schemes. Due to asymmetrical information on the size of the risk between the insurer and the insured the premium will be set at an average level. ${ }^{13}$ For the low-risk members of the group this premium will be relatively too high, which will lead the good risks to leave the risk pool. According to Priest this leads to a process whereby always the best risks will be leaving the pool, which leads to an overall unravelling of the risk pool. In a recent article he argues precisely that the current insurance crisis in the US has been caused by this incurable adverse selection problem. ${ }^{14}$ His defence is that these problems are much more serious in third party insurance than in a first party insurance scheme and that the development toward an increasing use of third party insurance schemes has caused the insurance crisis in the US. If this were true one would of course have another strong argument against strict liability, since only under this rule will risk-averse injurers or producers take third party liability insurance.

In sum: the economic theory advances strong arguments in favour of a strict liability rule when consumers underestimate the risk of a product accident or when the harm is caused to third parties. However, if the victim has a substantial influence on the accident risk, or if the producer has market power and the consumers underestimate the accident risk, or if one takes into account the influence of insurance, strong arguments could be advanced in favour of a faull rulc.

\section{- 7.2.2 Crileria for (Product) Safety Regulation}

Next we also need to address briefly the question why product liability alone may not be sufficient to guarantee an optimal product safety. These issues have been addressed in the well-known 'criteria for safety regulation' developed by Wittman (1977) and Shavell (1984a, 1984b; see also Skogh, 1982).

\section{Information}

A first criterion, which may play a role in favour of ex ante regulation of product safety is the information needed to evaluate the risk. It is very possible that a government agency may ex ante be better able to evaluate the risk that certain products may cause harm and may in addition better evaluate the optimal way to reduce this risk, than private parties would. This may more particularly be the case if the costs for examining the optimal safety devices would be high. Ex ante regulation would thus pass on information to the market on optimal safety devices (Shavell, 1984, pp. 359-60; see also Silva and Cavaliere, 2000, pp. 297-8).

\section{insolvency}

A second, well-known criterion is insolvency. Liability rules (including product liability) obviously only deter if the manufacturer has money at stake to compensate his victim. Although many manufacturers may have large financial capacities, most of them are structured as corporations, which benefit from limited liability. Hence, as recent cases have shown, the risk that damage caused by product liability would be larger than the wealth of a manufacturer is real. In that case a problem of underdeterrence arises. ${ }^{15}$

It has, however, been pointed out in the literature that this problem of insolvency particularly causes underdeterrence in the case of strict liability and less so in the case of the use of a negligence rule. Indeed, under strict liability a problem of underdeterrence already arises as soon as the magnitude of the loss will be larger than the injurers' individual wealth. He will, in that case consider the accident as one with a maximum magnitude of his individual wealth and therefore only take the care necessary to avoid that accident. That care may be lower than the optimal care. Negligence has the advantage that the injurer continues taking care as long as his costs of care are lower than his wealth, since taking care will free the manufacturer from liability. ${ }^{16}$ This, 
therefore, once more balances the conclusion that strict liability may be the efficient rule for product liability. This is true on the condition that the insolvency problem can be cured, otherwise a risk of underdeterrence might arise.

Moreover, this insolvency problem may generally be an argument in favour of $e x$ ante regulation by government whereby a safety standard is set ex ante and enforced with sanctions. If, however, insolvency is the reason to introduce regulation, these sanctions should obviously be preferably of a non-monetary nature (Shavell, 1985).

\section{Deterrent effect of a tort suit}

There may, however, be a third argument which is probably the most powerful in favour of safety regulation in case of product accident, being the risk that manufacturers may, for many reasons, escape a liability suit. The reasons can be manifold (Shavell, 1984a, p. 363). Victims may have difficulties proving that their loss was caused by a product defect; this may be due, inter alia, to problems of proving causation. The most important problem is probably latency, being the fact that a long time lapse may happen between the moment that the product was put on the market and the moment that the damage occurs. If, for example, harm only occurs 20 years after a product was brought on the market, the manufacturer may already be out of business and can hence not be reached by tort law any longer. These are all powerful arguments in favour of applying safety regulations for product risks.

Combination of product liability and product safety regulation

Moreover, the literature has equally indicated that although there are, hence, strong arguments in favour of ex ante regulation of product risk, this is no argument to rely solely on regulation for a number of reasons. Regulation can be outdated fast, regulation is not flexible enough, there is always the risk of inefficient regulatory standards as a result of interest group activities and regulation is totally dependant upon public enforcement by inspectors and public prosecutors, which may be weak. For these and many other reasons, many have argued that product safety should be guaranteed both by ex ante regulation and ex post liability rules. ${ }^{17}$ However, one should be careful with this conclusion as well. Viscusi showed that in the American experience an overlap between regulation and product liability has caused inefficiencies (Viscusi, 1988). Of course it should be avoided that tort law leads to overdeterrence in the form of inefficient safety requirements (Silva and Cavaliere, 2000, 311-15).

So far we have therefore reached the conclusion that, from an economic perspective, a combined use of ex ante regulation and liability rules is justified to guarantee product safety. The question we will now have to turn to is whether it is also justified to regulate those issues at the European level. Before doing so we will first address how Europe has generally dealt with these issues.

\subsection{EUROPEAN PRODUCT LIABILITY AND PRODUCT SAFETY}

\subsubsection{Product Liability}

History and purpose of the Directive of $25 \mathrm{July} 1985$

A first draft was presented in 1974 but this was already modified in 1975 (see Reich, 1986). The first official Proposal for a Directive was presented by the Commission of the EEC on 9 September, 1976. ${ }^{18}$ This Proposal was debated in the Economic and Social Council ${ }^{19}$ and in the European Parliament, ${ }^{20}$ which both suggested important changes to the initial proposal, for example, with respect to the problem of development risks. Following these discussions, the Commission published a revised proposal in $1979 .{ }^{21}$ It was only more than five years later that the Council finally passed the Directive on 25 July, $1985 .^{22}$

Reading the Considerations, which precede the Directive, it is apparent that the purpose of the Directive was the approximation of the laws of the Member States. ${ }^{23}$ It was argued that this approximation was necessary, because the existing divergences between liability rules in the different Member States could distort competition. The various approaches to product liability in the Member States had led to different liability rules and safety standards. If product liability claims and investments in safety become an important factor in production costs, the different product liability rules might indeed result in different marketing conditions and could distort competition. For the same reasons, it is also held that differing levels of product liability might affect the free movement of goods within the common market.

The goal of approximating the laws of the Member States could be achieved through (the old) art. 100 of the EEC Treaty, which allowed harmonization through Directives of the EEC council in all cases where the functioning and establishment of the common market were directly concerned (see also Reich, 1986, p. 135). Since 'harmonization article' 100 was the legal basis for EEC jurisdiction in this matter, it is relevant to examine whether the Directive under discussion did indeed realize this harmonization objective. This point will be addressed below.

It is interesting to note that the considerations preceding the Directive refer not only to the possible distortion of competition and the endangering of the free movement of goods as justifying the need for harmonization, but also to the consumer protection argument. Indeed, the argument is advanced that the existing divergences in the product liability rules of the Member States might 'entail a differing degree of protection of the consumer property'. This harmonization of the level of consumer protection seems to have become an important goal of the Directive too. Consumer protection will not only be harmonized, as the first consideration suggests, but the level of consumer 
protection will also be increased. This becomes clear when reading the other considerations preceding the Directive, where the notion 'protection of the consumer' is mentioned as much as twelve times. So, this would indicate that the goal of the product liability Directive is not just to harmonize existing laws, but to harmonize them at a higher level of consumer protection. However, in this respect some authors suggest "that the primary motive for the EEC intervention is to create uniform marketing standards through harmonized liability rules and not the promotion of consumer interests'. They argue that one of the reasons for EEC harmonization was a fear that the American 'product liability explosion' might start in Europe too. In that respect the Directive would only be intended to stifle excessive Member States' initiatives based upon the US model. ${ }^{24}$

Main principles of the product liability Directive

It is, within the scope of the chapter, obviously not possible to provide a detailed overview of the contents of the product liability Directive; therefore a brief overview of the main points will be provided.

The first article of the Directive gives the key rule for product liability, stating that the producer shall be liable for damage caused by a defect in his product. The following articles develop what is meant by the different notions which are used in article 1 . The considerations preceding the Directive make clear that this concerns a 'liability without fault'. A product according to article 2 means all movables which have been industrially produced. The Directive was not applicable to 'agricultural products and game'. These are 'the products of the soil, of stock farming and officeries' ${ }^{25}$ The producer according to the Directive is not only the manufacturer of a finished product. This is also the case for the producer of any raw material or the manufacturer of a component part. Also those, who, by putting their name, trademark or other distinguishing feature on the product, presen themselves as producer, are considered producers. The same is true for all importers of products into the community. Suppliers are, as a general rule, not liable under the Directive.

A product is considered to be defective under the Directive when it does no provide the safety which a person is entitled to expect. The consideration make clear that the defectiveness of the product should be determined by reference to the lack of safety which the public at large is entitled to expect. An element to be taken into account is the use to which it could reasonably be expected that the product would be put as well as 'the time when the product was put into circulation'. The burden of proof lies, according to article 4 , on the victim, who has to prove the damage, the defect and the causal relationship between the defect and the damage.

Non-liability clauses are invalid according to article 12 of the Directive.
There are, however, certain exclusion grounds for the producer. For example article 7 (b) excludes liability if the producer can prove that, having regard to the circumstances, it is probable that the defect which caused the damage did not exist at the time when the product was put into circulation by him or that this defect came into being afterwards.

Article 10 of the Directive states that a limitation period of three years shall apply to proceedings for the recovery of damages. In addition article 11 provides that the rights of the victim pursuant to the Directive shall be extinguished upon an expiry of a period of 10 years.

Finally article 16 of the Directive introduces the option for the Member States to limit the producers' liability to an amount which may not be less than 70 million ECU if the damage resulted from death or personal injury and if it was caused by identical items with the same defect (so called serial damage).

The green paper on liability for defective products makes clear that the goal of the Directive was to provide a balanced approach providing, on the one hand, a protection to victims, but avoiding, on the other hand, a 'crushing liability', for example by requiring the victim to prove the defective nature of the product and by providing limitations in time. ${ }^{26}$

\subsubsection{Product Safety}

\section{Goals and purpose}

In addition to the product liability Directive the Commission has also issued a variety of Directives providing harmonized safety standards for specific items, such as machines, for example. Moreover, on 29 June 1992 a Council Directive $52 / 59$ on general product safety was issued. This Directive clearly aimed at removing differences in safety standards, since the Commission considered that those differences might endanger the establishing of the internal market. The goals of this Directive are probably best understood by citing the considerations:

Whereas it is important to adopt measures with the aim of progressively establishing the internal market over a period expiring on 31 December 1992; whereas the internal market is to compromise an area without internal frontiers in which the free movement of goods, persons, services and capital is insured;

Whereas some Member States have adopted horizontal legislation on product safety, imposing in particular, a general obligation on economic operators to market only safe products:

Whereas those legislations differ in the level of protection afforded to persons:

Whereas such disparities and the absence of horizontal legislation in other Member States are liable to create barriers to trade and distortions of competition within the internal market. 
This Directive therefore had as its goal to remove trade barriers, which could result from differing product safety standards, within the framework of the internal market programme.

According to Silva and Cavaliere $(2000$, p. 312) European regulation of product safety has always been concerned with two main aims: (1) To guarantee a minimum level of safety to all European consumers, and (2) to harmonize the different national legislation in order to prevent the crection of non-tariff barriers to free trade among European countries.

\section{Main principles}

The Directive contains, inter alia, in article 3 a general obligation on producers to place only safe products on the market. Producers are also expected to provide consumers with the relevant information to enable them to assess the risks inherent in a product throughout the normal or reasonably foreseeable period of its use.

However, article 4 of the Directive provides that:

where there are no specific community provisions governing the safety of the products in question, a product shall be deemed safe when it conforms to the specific rules of national law of the Member State in whose territory the product is in circulation, such rules being drawn up in conformity with the treaty, and in particular article 30 and 36 there of and laying down the health and safety requirements which the product must satisfy in order to marketed.

In other words, this general product safety Directive functions as a stopgap for issues not covered by other Directives fixing harmonized safety standards. In the absence of specific community provisions the conformity of a product to the general safety requirement shall be assessed having regard to voluntary national standards giving effect to a European standard or, where they exist, to community technical specifications or, failing these, to standards drawn up in the Member State in which the product is in circulation, or to the code of good practice in respect of health and safety in the sector concerned.

The considerations preceding the Directive and article 13 of this general product safety Directive specify that this Directive does not affect victims' rights with respect to the product liability Directive. In other words it is not because a product is considered 'safe', because it corresponds with a code of good practice, that this would mean that the product can no longer be considered defective within the meaning of the product liability Directive.

The Directive moreover provides for specific obligations on the Member States to make regulations in such a way that products placed on the market are safe and it contains a duty to notify the Commission of the measures taken under the general product safety Directive.

\subsection{CRITERIA FOR (DE)CENTRALIZATION}

\subsubsection{Starting point: 'bottom up federalism'}

The question whether regulation should be promulgated at central (European or federal) level or at a more decentralized level (or, to put it in a more balanced way, what kind of regulations should be set at which level) has been addressed in the economics of federalism. The starting point for the analysis is usually the theory of Tiebout about the optimal provision of local public goods. ${ }^{27}$ Tiebout argued that when people with the same preferences cluster together in communities, competition between local authorities will, under certain restrictive conditions, lead to allocative efficiency. If, for example, there are in one community citizens with a high preference for sporting facilities and in another one a majority of citizens with a preference for opera, the first community will probably construct sporting facilities, whereas the second will probably provide an opera house. If someone living in the second community would prefer sporting facilities instead of the opera house, he could then move to the first community, which apparently provides services that better suit his preferences. The idea is that well-informed citizens will move to the community that provides the local services that are best adapted to their personal preferences. Through this so-called 'voting with the feet' competition between local authorities will lead citizens to cluster together according to their preferences. In practice one can notice that different communities do indeed offer a variety of different services. The idea is that the citizen can influence this provision of local public goods either by influencing the decision making (vote) or by moving (exit).

This basic idea applies not only to community services, but also, for example, to fiscal decisions (see, for example, Inman and Rubinfeld, 1994; Kirchgässner and Pommerehne, 1993; Oates, 1972) and environmental choices (see Oates and Schwab, 1988). In addition, this idea of citizens moving to the community that provides services which best correspond with their preferences can also be applied with respect to legal rules. Thus, it has been argued by Van den Bergh (1994) that a competition between legislators will lead to legal systems competing against each other, to provide legislation that corresponds best to the preferences of citizens. Also Ogus (1999) argued that the various lawmakers in the nation-states would create competitive market for the supply of law. The idea therefore is that in an optimal world, citizens will cluster together in states that provide legal rules that correspond to their preferences. Well-informed citizens, who may be dissatisfied with the legislation provided, could move (voting with the feet) to the community that provides legislation that corresponds best to their preferences. This idea, assuming that those different legal systems offer different legal rules thus 
explains the variety and differences between the legal systems (Van den Bergh, 1998, p. 134). Moreover, it also shows that differences between the various legal rules of different countries should not necessarily be judged as negative, as is often the case in Europe today. The idea of competing legal systems can probably best be seen 'in action' in international private law where actors can choose the legal systems that best suit their needs in a choice of law regime. ${ }^{28}$ Frey and Eichenberger have proposed an extreme form of this competition between legal orders by suggesting the emergence of Functional Overlapping competing Jurisdictions (FOCJ), whereby citizens could choose different governmental unities for different functions of government (Frey, 1996; Frey and Eichenberger, 1996; Casella and Frey, 1992). See in this respect also the contribution by Frey included in this volume

Obviously, this system, assuming that a competition between legal orders leads to allocative efficiency in the provision of legal rules, works only if certain conditions are met. One condition is that citizens have adequate information on the contents of the legal rules provided by the various legislators, in order to be able to make an informed choice. In addition, exit is often costly, so people may stay even if the (legal) regime does not suit their needs optimally. ${ }^{29}$ Moreover, a location decision is obviously made under the influence of a set of criteria, whereby the legal regime may not be decisive. ${ }^{30}$ Usually the job location and residence are that important that in reality there is often little left for people to choose (Rose-Ackerman, 1992a, p. 169). Finally, as we will discuss below, this system of competition between legal orders works only if the decisions in one legal order have no external effects on others.

In economic literature, this Tiebout model is used to argue that, from an economic point of view, decentralization should be the starting point, since competition between legislators will lead to allocative efficiency. Van den Bergh uses this theory as well to provide criteria for centralization/decentralization within the European Union. Taking Tiebout as a starting point and assuming that competition between decentralized legislators will lead to an optimal provision of legal rules, the central question is: why centralize? Van den Bergh therefore criticizes a part of the current discussion in the European legal literature which seems to focus on the question why there should be decentralization (referred to by Van den Bergh as 'top down federalization'). According to economic theory, that is the wrong question. Starting from Tiebout's model, there is reason to believe in what Van den Bergh calls a 'bottom up federalization', assuming that in principle the local level is optimal, since the local level has the best information on local problems and on the preferences of citizens. Only when there is a good reason, should decision making be moved to a higher level. ${ }^{31}$ Economic theory has indeed suggested that there may be a variety of reasons why the local level is not best suited to take decisions and where central decision making can lead to more efficient results.
These criteria for centralization will now be applied to product liability and product safety.

\subsubsection{Transboundary Character of the Externality}

The Tiebout argument in favour of competition between local communities obviously works only if the problem to be regulated is indeed merely local. Once it is established that the problem to be regulated has a transboundary character, there may be an economics of scale argument to shift powers to a higher legal order that has competence to deal with the externality over a larger territory. This corresponds with the basic insight that if the problem to regulate crosses the borders of competence of the regulatory authority, the decision-making power should be shifted to a higher regulatory level, preferably to an authority which has jurisdiction over a territory large enough to adequately deal with the problem (compare Ogus, 1998, p. 414; Kimber, 1995; Esty, 1996 and Rose-Ackerman, 1992a, pp. 164-5). 'Economic theory provides a straightforward but unrealistic answer to regional pollution problems: draw 'optimal' jurisdictional boundaries' (see Rose-Ackerman, 1995, p. 38).

This externality argument in favour of centralization traditionally plays an important role with respect to environmental problems (see Oates and Schwab, 1988 and Van den Bergh, 1998, p. 140). The question, however, arises how this 'transboundary externality' argument relates to product liability. One can certainly argue that the product liability area is a totally different one from the traditional tort as far as the potential of affecting international trade is concerned. The chance that 'normal' tort might have an interstate effect is, with a few exceptions (like the transboundary pollution case), relatively small, whereas, given mass production, products nowadays are seldom just meant for the national market. Indeed, as Schwartz argued in the American context, the imperatives of mass production require a manufacturer to sell the same product throughout the nation, so that the need for uniformity in product liability law seems huge (Schwartz, 1996, p. 924). For the same reason Ackerman (1996, p. 451) argues that product liability is in principle a good candidate for national law. These arguments, however, mainly amount to the point that uniformity in product liability law would come in 'handy' in the American context, ${ }^{32}$ they do not explain why the mere fact that products cross nationa borders would constitute the risk that states would be able to shift external costs to others.

Indeed, the starting point for the analysis remains, as Van den Bergh rightly points out, that different communities in the Member States may have different preferences concerning both the level of product safety and product liability law. The fact that these differing preferences lead to differing legal 
solutions should in principle, as discussed above, be considered as a benefit instead of a problem (Van den Bergh, 1998, pp. 133-4). He therefore argues that a problem only arises if, for example, a producer in the Netherlands would produce products which comply with the Dutch (supposedly low) product liability and product safety standards and would largely export products to, say, Belgium and France, where (again supposedly) the required level of product safely would be much higher. In this hypothesis a 'transboundary externality' problem would only arise if the consumers in Belgium and France would not have the possibility to file a lawsuit against the Dutch manufacturer. This problem is, however, not very realistic since the victims will in this case be the French and Belgian citizens who presumably have a higher product liability standard which would then also be applied on the Dutch manufacturer. In other words, manufacturers of defective products are generally liable in damages for harm suffered in export markets (see Van den Bergh, 1998, p. 141).

of course the fact that, in the example given, the manufacturer is located in the Netherlands and the products are marketed in Belgium and France, and the harm is suffered equally in those countries, may lead to a few practical problems for victims, but these do not necessarily immediately justify central regulation with the corresponding loss of differentiated regulation according to preferences. First of all, choice of law regimes may be used to guarantee, for example, that the French and the Belgians can have their (supposedly higher standard) product safety and product liability law applied. This, however, is criticized by Schwartz who points at the fact that in this example the court in say, France, will apply high standard French law on the Dutch manufacturer. The effect therefore is that the Dutch manufacturer will be confronted with the higher standard French law. From this Schwartz implies that a regime of state product liability law is hence inconvenient as a means for expressing state values. In the view of Schwartz (1996, pp. 931-2, 937-41) France would express its sovereignty by subordinating the sovereignty of the Netherlands through the application of French law. Still, it can hardly be seen how this argument can justify central regulation. The effect of the choice of law regime is precisely that the Dutch manufacturer will not be able to externalize harm by shifting this oniy to export markets. Of course this presumes that a system is in place which allows the Belgian and French victims to sue the Dutch manufacturer. But this is, in the European context, precisely given through the (recently revised) European Convention with respect to the jurisdiction and execution of judgements of 1968. Of course one should be aware that even with this convention it might still remain difficult for victims to recover losses in another state (see Kirstein and Neunzig, 1999). This practical problem can, however, not be remedied by harmonization. It is indeed not differences in legal rules that cause difficulties in the transboundary enforcement of claims, but different rules of civil procedure in the Member States.
In sum, the mere fact that different states would hold different preferences with respect to product liability and product safety and that therefore different regimes would exist, can, as such, hardly be considered as an argument for centralization as long as states are not capable of externalizing harm to victims in third countries. A problem might in that respect merely exist, so Van den Bergh has argued, if the rules of the import country do not allow a full internalization because the injurer may escape the payment of damages. Van den Bergh gives the example of a situation where a state would not allow recovery in tort in case of causal uncertainty, meaning that the manufacturer would not be held liable unless the victim can prove 'beyond reasonable doubt' that the particular manufacturer caused his loss. A problem could, according to Van den Bergh (1998, p. 142), also arise if a legal system would not allow recovery of non-pecuniary losses. In those cases there would be inefficiencies in national product liability law of the importing state which would indeed allow exporting manufacturers to externalize harm. This, however, assumes for example that the decision not to compensate non-pecuniary losses would be inefficient and would not be a reflection of national values and preferences of citizens.

\subsubsection{Race for the Bottom}

There may be an economic argument for a regulation of product safety problems, in that there is a risk that a 'race to the bottom' between countries would emerge to attract foreign investments. As a result of this, prisoners' dilemmas could arise, whereby countries would fail to enact or enforce efficient legislation. Centralization can be advanced as a remedy for these prisoners' dilemmas. This race for the bottom argument could, in theory, play a role in the case of product safety as well. ${ }^{33}$ It would mean that local governments would compete with lenient product safety regulation to attract industry (compare Rose-Ackerman, 1992a, pp. 166-170). The result would be an overall reduction of product safety below efficient levels. This should correspond with the traditional game theoretical result that prisoners' dilemmas create inefficiences.

The basic idea behind this argument applied to product liability would be that product liability law may impose costs on industry. If governments highly fear these costs and would prefer to favour national industry, they could do so by lowering product standards. If lowering product standards would be a way to attract industry, distortions could occur which would justify centralized decision-making.

There are, however, some weaknesses in the application of this argument on the area of product safety. First of all product liability and product safety law may effectively create costs for the manufacturing industry but, as was 
explained in the economic analysis above (see Section 7.2) these costs can often be passed on to the purchasers of the product (Van den Bergh, 1998, pp. 137-9). Second, in as far as the liability of a producer in the sense of the product liability Directive (being the manufacturer) is concerned, it is difficult for states to engage in a race to the bottom for the simple reason that the harm may well occur in another state. Imagine, again, that France would like to attract industry with a lenient product liability regime. In doing so it can hardly attract manufacturing industries that largely depend upon the export market. Their exposure to product liability will indeed depend upon the legislation applicable in the state where the harm will occur. It is, therefore, especially as far as the liability of manufacturers is concerned, unlikely that states would engage in a race to the bottom to attract industry (see Ackerman, 1996, p. 458 and Van den Bergh, 1998, p. 139).

This shows that the theoretical basis for a race to the bottom risk in case of product liability is relatively weak (Van den Bergh, 1998, pp. 136-7). This argument would only justify centralization if it could be proven that without centralization a risk of destructive competition would indeed emerge. ${ }^{34}$ There is no proof of such a destructive competition towards lower product safety standards and this risk is, moreover, not very realistic (Faure, 1998, pp. 46-7). Indeed, one can doubt that the law of tort, and more particularly product liability, plays a significant role in attracting or repulsing businesses to or from a given state. Other elements, such as labour conditions, the amount of direct government regulation and taxes may be far more important than the level of product liability in location decisions of business (Ackerman, 1996, p. 459). Moreover, if product liability were to have any effect as far as a race for the bottom is concerned, it is even more likely that states would wish to protect accident victims instead of corporate interest. Consumer advocates may call this a 'race for the top', although a system whereby foreign manufacturers are penalized with overprotective product liability law may well be considered inefficient and in that (reverse) sense a race towards the bottom (Ackerman, 1996, p. 458 and Schwartz, 1996, p. 932).

\subsubsection{Harmonizing Marketing Conditions}

In the European debate the question of centralization has never focused on the race to the bottom. In Europe a different, somewhat related, argument has been used to harmonize legislation of the Member States in a variety of areas. This has been the legal argument that the creation of harmonized conditions of competition is necessary to avoid trade distortions. Simply stated, the argument runs that complying with legislation imposes costs on industry. If legislation is different these costs would differ as well and conditions of competition within the common market would not be equal. This argument apparently assumes that total equality of conditions of competition is necessary for the functioning of the common market. This argument, also referred to as 'levelling the playing field for European industry' is obviously closely related to the desire to create a common European market. This 'harmonization of conditions of competition' argument is different from the economic race for the bottom argument and more linked to the European political idea of the creation of the common market. It is the traditional argument that uniform rules in Europe are necessary to guarantee free movement of goods within the EC (see Van den Bergh, 1998, p. 136). What can be said about this argument?

Probably a difference should be made in this respect between product safety standards on the one hand and product liability rules on the other hand It could be argued that differences in product safety standards may indeed endanger interstate trade. Therefore rules with respect to, inter alia, a free flow of products and services may certainly contribute to the European goal of market integration. Where the preamble to the Directive of 29 June 1992 on general product safety states that disparities and the absence of horizontal legislation in other Member States are liable to create barriers to trade and distortions of competition within the internal market, this is probably true. However, the question arises whether these goals of market integration can only be achieved via this far-reaching instrument of total harmonization and more particularly the question arises whether this may justify a harmonization of rules of private law, such as product liability. Indeed, the political goal of market integration may justify the need for some rules aiming at the reduction of trade restrictions (think about the case law of the European court of justice with respect to the free movement of goods) and may justify a minimum harmonization of product standards in the framework of the single market initiative. In that respect the Directive on general product safety in fact only provides for a general obligation to place only safe products on the market, but safety standards may still be drawn up in the Member State in which the product is in circulation or may rely on codes of good practice, which need not necessarily be European. ${ }^{35}$

Ogus (1994, pp. 177-9) is relatively enthusiastic on these product safety directives, precisely because the harmonization is limited to 'essential safety requirements'. To meet these requirements the member stages can still use their national standards, whereby voluntary standards set by expert committees will allow for an easy mutual recognition. The approach chosen in the product safety directives, therefore, even promotes competition between different national and European standard systems, so Ogus holds.

The goal of 'levelling the playing field' is much more apparent in the product liability Directive. That Directive is clearly justified on the ground that differing liability rules in the Member States would hamper the conditions of competition. The considerations preceding the Directive read: 
Whereas approximation of the laws of the Member States concerning the liability of the producer for damage caused by the defectiveness of his products is necessary because the existing divergences may distort competition and affect the movement of goods within the common market.

The weakness of this argument is that it assumes that differences in marketing conditions are always and necessarily a problem for the creation of a common market. Conditions of competition are obviously never equal, as the 'levelling the playing field' argument assumes. In the ideal case of totally equal marketing conditions, there would also be no trade. This political goal of market integration may moreover be questioned on economic grounds. ${ }^{36}$ In addition one should realize that even if product liability law were totally harmonized in Europe, this would still not create a level playing field, since differences in, for example, energy sources, access to raw materials and atmospheric conditions will still lead to diverting marketing conditions (see Van den Bergh, 1999, p. 6).

There is, in addition, a strong counterargument, in that there are many examples showing that economic market integration is possible (without the distortions predicted by the race for the bottom argument) with differentiated legal orders. Public choice scholars have often advanced the Swiss federal model as an example where economic market integration goes hand in hand with differentiated legal systems (Frey, 1994). It is apparently possible to create a common market without a total harmonization of all legal rules and standards (see equally Revesz, 1997, pp. 1338-41).

Finally, 'the proof of the pudding is in the eating'. The question can therefore be asked whether the European product liability Directive, as it has been drafted, can indeed achieve a total harmonization of marketing conditions. This question will be addressed in the next section.

\subsubsection{Transaction Costs}

There may, however, be one final economic argument in favour of harmonization, based on transaction costs reduction. ${ }^{37}$ This argument is often advanced by European legal scholars pleading for harmonization of private law in Europe, and is based on the argument that differences in legal systems are very complex and only serve Brussels law firms. ${ }^{38}$ This argument cannot be examined in detail here. ${ }^{39}$ It is obviously too simple to state that a harmonized legal system is always more efficient than differentiated legal rules because of the transaction costs savings inherent in harmonized rules. ${ }^{40}$ This argument neglects the fact that there are substantial benefits from differentiation whereby legislation can be adapted to the preferences of individuals. ${ }^{4}$ Moreover, given the differences between the legal systems (and legal cultures) in Europe the costs of harmonization may be huge - if not prohibitive - as well. ${ }^{42}$ The crucial question therefore is whether the possible transaction costs savings of harmonization outweigh the benefits of differentiated legal rules There is little empirical evidence to support the statement that transaction costs savings could justify a European harmonization of all kinds of legal rules. Moreover, the transaction cost savings are likely to be relatively small (see Vall den Bergh, 1998, pp. 146-8). However, the transaction costs argument may play an important role to justify, again, a coordination of product safety standards to prevent states from hindering a free flow of products and services (see generally Vogel, 1995, pp. 52-5). Indeed, some cooperation between states seems necessary to avoid that if a product is mass produced and internationally distributed, interstate trade would be hampered as a result of varying national product safety standards (Schwartz, 1996, pp. 924-5) Indeed, also in international law it is well known that diverging health, safety and related regulatory standards between countries of origin and countries of destination, especially in cases where these standards are more stringent in countries of destination, provide a source of allegations by countries of origin that they are subject to discrimination in countries of destination. This might result in a violation of the GATT and regulatory harmonization will therefore occur to minimize product incompatibilities to allow producers to maximize access to export markets. Harmonization is therefore certainly useful to avoid pointless incompatibilities which do not reflect different preferences (Trebilcock and Howse, 1998, pp. 21, 30). These transaction costs arguments do therefore apply in the field of economic regulation and product safety Indeed, the information required to formulate these rules may be useful for the whole of Europe and the formulation of uniform rules in these cases may save on information costs and can, hence, promote interstate trade. Therefore, once more, the Directive on general product safety, taken in the framework of the 1992 programme to establish the internal market, may well be considered as an instrument which saves on transaction costs (Van den Bergh, 1998 , pp. 145-6).

The question, however, arises whether these transaction costs savings as a result of harmonized rules can also be expected for product liability. One could argue that a manufacturer who markets his products Europe-wide would, in the absence of harmonization, need specialized legal counsel in every state and their insurance underwriters would have to calculate the liability exposure separately in accordance with each state's product liability law (Ackerman, 1996, p. 453). This argument, however, as mentioned above, neglects the fact that there is a benefit in differentiated liability rules, which reflect varying preferences. Moreover, the costs of harmonization in the field of private law (which is so rooted in legal culture) may be huge and the alleged transaction costs savings may be less than expected. Indeed, even in the case of a harmonized 
legal rule, manufacturers still would need local counsels to try cases Accordingly, scale economies under a harmonized rule would likely be insignificant (see Ackerman, 1996, p. 453, note 135). Here again 'the proof of the pudding is in the eating', so that the question arises whether the European product liability Directive has been able to create the legal certainty required, reducing transaction costs for manufacturers. ${ }^{43}$

One may conclude so far that there are a few arguments in favour of harmonized product safety standards, the most important one being the faciliating of interstate trade via uniformity and reduced transaction costs. There are, however, fewer arguments at first sight in favour of harmonized product liability rules.

\subsubsection{Balance}

The result of applying the criteria advanced by Van den Bergh (see his contribution to this volume) to products liability is that there would be arguments in favour of centralized European rule making if (1) there would be inefficiencies in national product liability law which would allow manufacturers to externalize damage caused by product defects, or (2) if it would be established that states could attract industry with lenient product safety standards. The latter is, however, unlikely, since states would to the contrary enact legislation to protect victims of product accidents within their own jurisdiction with high standard product liability legislation. There may be transaction costs savings of uniform product liability law if a Directive were able to create legal certainty and achieve a full harmonization, which needs to be examined below. The answer to that question is also relevant to verify the justification given by the European Commission for the European product liability Directive, being that it would harmonize marketing conditions in Europe. The question therefore arises whether the European product liability Directive has been able to achieve these goals.

\subsection{EFFECTIVENESS OF THE PRODUCT LIABILITY DIRECTIVE OF 1985}

\subsubsection{Goals of the Directive}

As we have stated above (see Section 7.3.1) the European products liability Directive had two goals: first, it aimed at creating equal marketing conditions to 'avoid distortions of competition'. Second, it wished to achieve a high level of consumer protection. Both goals can, within the focus of this paper, be rephrased in economic terms. The question whether the product liability Directive actually leads to harmonization is obviously useful to judge the desirability of a European action in the first place. If the Directive would have been able to create full harmonization of product liability, it might have created transactions costs savings to such an extent that they may have outweighed the advantages of differing product liability laws. The question whether the contents of the Directive leads to an increased consumer protection may simply be rephrased by asking whether the product liability regime chosen in the Directive promotes economic efficiency.

\subsubsection{Uarmonization}

A first question which had to be asked is whether the justification given in the considerations preceding the Directive, being that the existing divergences before the product liability Directive may distort competition and affect the movement of goods within the common market, is actually correct. It is undoubtedly true to argue that before 1985 there were different product liability regimes in the Member States, but the question arises whether these differences were that important that they 'may distort competition and affect the movement of goods within the common market', as the product liability Directive argues. A Dutch author, Van Wassenaer van Catwijck (1986b), has indicated that although the product liability regimes did indeed differ, insurance premiums for the coverage of the product liability risk were not substantially different. If that is true, the differences in marketing conditions were probably not as large as the Commission holds. More important is obviously the question whether the Directive in the 1985 version could reach the harmonization goal at all. It is in fact very unlikely that this is the case. ${ }^{44}$

Indeed, according to article 13 all the different, already existing, product liability laws remain in effect, which means that already existing differences will remain unchanged. In addition at many points the Directive itself refers to national legislation, for example with respect to the rights of contribution or recourse (article 5 and 8,1), with respect to non-material damage (article 9), the suspension or interruption of the limitation period (article 10,2) and with respect to nuclear accidents (article 14). It should also be mentioned that in three cases the Directive expressly allows the Member States to derogate from the provisions of the Directive - namely liability for primary agricultural products, liability for development risks and the introduction of a financial limit on liability. Moreover, the Directive cannot of course bring any harmonization for all the product accidents to which it does not apply, because of limitations in the definitions of 'product', 'producer' and 'damage'. Many notions in the Directive are also unclear and can give rise to interpretation problems. ${ }^{45}$ These problems might lead to different interpretations of the provisions of the Directive by the legislator and courts of the different Member States. These interpretation problems can be solved by the European Court of Justice in 
Luxembourg. But it often takes a long time before an interpretation problem is brought before the Court and as long as there is no definitive solution, these interpretation problems of unclear notions in the Directive might again endanger the harmonization objective. Interpretational problems are all the more likely in practice since even the language differences of the various translations of the Directive can lead to different interpretations of the same provision. ${ }^{46}$ It was just mentioned that the product liability Directive gave several options to the Member States, concerning the including of primary agricultural products, the liability for development risks and the possibility of introducing a financial limit on liability. This has obviously also caused differences, as we just indicated. These differences as far as the transposition of the Directive in domestic law is concerned are shown in annex 1 to the green paper on liability for defective products which is included in the annex to this chapter.

Since it is clear that this product liability Directive cannot reach an approximation of the Member States legislation, it has been suggested that this was only used as an argument to give the EC competence in this matter. ${ }^{47}$

There are other inconsistencies that are worth mentioning in an effectiveness evaluation of the Directive. Both the introduction of the 10 year extinguishing period and the optional introduction of a financial limit on liability have been defended by referring to the introduction of liability for development risks. In the final version the producer is in principle not liable for development risks, but nevertheless the extinguishing period as well as the optional financial limit remained, although the reason given has disappeared. In addition one notices that the Directive is said to introduce a 'liability without fault', but nevertheless the conduct of the producer will still be important, for example when the defectiveness of a product is assessed and with respect to the defect notion. So, in fact, the fault notion still plays a role in establishing whether there is liability under the Directive.

For all these reasons some authors qualify the Directive itself as a defective product. ${ }^{48}$

\subsubsection{Efficiency and Consumer Protection}

The Directive also claims to provide an increased consumer protection. The question arises whether the Directive is indeed aiming at the protection of consumers. Moreover, this question can also be rephrased by asking whether the Directive promotes economic efficiency, by comparing the regime of the Directive with the economic model explained above.

Consumer protection?

As far as the 'protection of the consumer' is concerned one can argue that in comparison with existing product liability schemes in some Member States, for example Germany and France, the Directive can not add a lot as far as consumer protection is concerned. ${ }^{49}$

Indeed, damage caused by primary agricultural products was excluded from the scope of the Directive. For material damage there is a lower threshold. There are short limitation and extinguishing periods. The Member States can even introduce a financial limit on liability. One could oppose these remarks on the basis that for some countries, which had no product liability system at all ${ }^{50}$ the Directive substantially improves the situation of the victim of a defective product. One could say the same for countries which already had a product liability system since, according to article 13 , the liability system of the Directive is only added to the already existing system so that the victim is always better off. This is, however, only true on a short-term basis. Most authors hold that the Member States are not allowed to introduce after 30 July, 1985 a product liability system which would give more rights to the victim than does the Directive (see Duintjer Tebbens, 1986, p. 373 and Van Wassenaer van Catwijck, 1986b, p. 81). This interpretation is also followed in the green paper. If this were true, then the Directive does limit the right of Member States and also limits the protection of the consumer in the future. ${ }^{51}$ It is therefore unclear even whether the Directive does indeed provide consumer protection, certainly when one regards this on a long-term basis. ${ }^{52}$

A detail which should also be mentioned, is that the notion consumer protection, which is so often used in the considerations preceding the Directive, is in fact misleading. A 'consumer' is a purchaser, who buys a product. The Directive is, of course, not at all limited to a protection of the buyer of the product. Also third parties that suffer harm from a defective product can benefit from the protection of the Directive. Indeed, for many Member States the main improvement of the Directive is that also third parties now benefit from the strict liability of the producer. The damage suffered by someone who stood in a contractual relationship with the producer (the consumer), was often already subjected to strict liability of the producer. In addition, the damage caused to a victim 'as consumer' being the damage caused to the purchased product itself, is excluded by the Directive (Article 9 (b)). For these reasons it appears that the term consumer protection which is so often used with respect to the Directive, is not that well chosen. What is meant is the protection of the victim, whether this is a consumer or not.

Some economic effects of the EC Directive ${ }^{53}$

Apparently the drafters of the EC Directive judged that the best way to realize the protection of the consumer, of which they spoke so much, was to implement a generalized strict liability rule for harm caused by a product defect. The first thing that is striking when one compares this rule with the economic theory of product liability discussed above, is that the Directive advances one 
single rule to deal with all product accidents, whereas the economic theory is much more balanced and detailed. Depending upon whether or not the victim is a consumer, whether the latter has information on the product risk, what the influence of insurance is and so on, economic theory would only hold that a strict liability rule is efficient in some cases, but certainly not in all.

At the policy level it is, using all the relevant criteria, almost impossible to give advice to the legislature to use one single rule for all product accidents. There is even a question as to whether the legislator would have to define such a rule. An obvious alternative would be to let the judge decide what type of liability rule should govern the product accident. Thus case law could take into account all the relevant criteria and the application of the strict liability rule could be limited to certain product accidents. The Directive, which introduces one strict liability rule for all product accidents, disregards all the various factual situations, which make different liability rules efficient. Thus, by using one single rule inefficiencies will unavoidably be created since the strict liability rule will also be applied where this would be inefficient taking into account the abovementioned criteria. It is also doubtful whether the savings in administrative costs by using one legal rule outweigh the inefficiencies. The costs of applying the economic criteria for strict liability should not be that high either Particularly if they can easily be recognized (for example whether the victim was a consumer or a third party) an individualized product liability system where strict liability will only be applied in some cases could be used by the judge at relatively low costs.

One of the criteria was also applied for a long time in legal practice. Indeed, in most legal systems, product accidents whereby the victim stood in a contractual relationship with the producer were treated differently from those where the victim is a complete stranger to the producer. One of the reasons for introducing the generalized strict liability in the Directive was that this different treatment was considered 'unjust'. However, this distinction is quite sound from an economic point of view. As was mentioned above, if the victim stands in a contractual relationship with the producer a Coasean solution is in principle possible if the consumer is well informed on the accident risk. Such a solution is, of course, always excluded in the event that the victim is a third party because of the prohibitive transaction costs. So there is a good economic reason for treating both situations differently.

Of course the EC Directive does not introduce a general strict liability rule for all damage caused by a product. The produce will only be liable when the damage was caused through a defect in the product. It looks as if this is more a fault liability since a product is often defective because the producer did not take sufficient care. However, liability is indeed strict since the producer will always incur liability when harm was caused by a defect in his product even if he can prove to have taken due care. The producer only escapes liability when the harm was not caused by a defect of the product. Given the broad defect notion in the Directive a product is almost already considered defective by the mere fact of having caused the harm. ${ }^{54}$ Therefore, there is not, from an economic point of view, a substantial difference between a strict liability for all damage caused by a product and strict liability for damage caused by a defect in the product as in the Directive. ${ }^{55}$ It was mentioned above that the general strict liability rule for all activities, which is used in the Directive, might create inefficiencies since it will also be applied in cases where a fault rule would be preferable from an efficiency viewpoint. It should not be forgotten, however, that the purpose of the Directive was the harmonization of product liability law in Europe. If this should succeed it could create benefits which could easily outweigh the disadvantages of the generalized strict liability rule discussed above. Indeed, if a single product liability rule were to be created in all Member States this could contribute to the creation of equal marketing conditions and thus to the realization of the internal market. This could bring substantial savings (compare Van den Bergh, unpublished manuscript), which could easily outweigh the inefficiency of the use of a single rule. This, however, will not be the case in practice since it was shown in the previous subsection that the Directive can never bring a harmonization of product liability law in Europe. So the inefficiencies remain without any compensating benefit for the realization of the internal market.

\section{Distributional effects}

One could go one step further and argue that the Directive does not only create several inefficiencies, but that it is also problematic from a distributive point of vicw. Many lawyers favour the introduction of strict liability since it would protect the consumer. It is even argued that strict liability would be necessary to restore the broken balance between producers and consumers. The Coase theorem teaches that also from a distributive point of view there will be no difference between a fault rule and a strict liability rule. Fully informed consumers will only take into account the full price of the product (cost price + expected accident costs) and will base their purchase decision upon this full price. Even if the legislator would like to protect the consumer by introducing a strict liability rule, the producer will still add the expected accident costs to the cost price. The consumer will again pay the full price since the expected accident costs are passed on to him, which is reflected in a higher market price. Since producers and consumers are bound through the price mechanism, every shift of liability to the producer will be passed on to the consumer. In this setting a legal intervention to redistribute wealth to the consumer by introducing a strict liability rule seems therefore useless (see Hamada, 1976).

When consumer groups are heterogeneous, the introduction of strict liability will even have adverse distributional effects. Indeed, the most important 
part of damages is lost income. The expected damages are therefore of course higher for high-income consumers than for low-income consumers. The producer will, however, take into account an average expected damage and will add this to his cost price to get one single market price for all consumers. The effect is that when low-income consumers still buy the product, they 'pay' for the expected damages of the high-income consumers. Therefore stric liability in a product liability setting creates a redistribution from poor to rich consumers (see Adams, 1987, pp. 6-7). For the same reason Priest argued that the product liability explosion the US hurts especially the low-income groups (Priest, 1987).

This effect will be stronger still when the strict liability rule does not only apply on harm suffered by consumers, but is extended to damages caused to third parties, as the EC Directive does. In that case the market price will again be higher since the producer will also have to pay for damage caused to third parties. The increased expected damages will again be passed on to the consumer who pays a higher market price for the damage a product he bought can cause to third parties. The consumer has no possibility to pass on this increased price and therefore he, in effect, pays for the protection of third parties.

So the expansion of strict liability to damage caused to third parties redistributes wealth from consumers (of the product) to third parties. Consumers will indeed have to pay for the protection of third parties. This again increases the adverse redistributive effect of poor consumers paying higher prices for the expected damages of third parties. Since lost income is an important part of the damage, again the high-income groups do indeed benefit from the redistribution.

This shows that the generalized strict liability which has been introduced by the EC Directive will not only create inefficiencies, but is also based on wrong ideas concerning the protection of consumers.

\section{Curing externalities?}

So far, in our analysis of the European product liability Directive, we argued that the Directive can hardly lead to a harmonization of marketing conditions or to a lowering of transaction costs (given all uncertainties and information problems). Another point, made by Van den Bergh, is that the product liability Directive can also not be considered to cure the risk of externalizing damage caused by defective products since the Directive does not address the issue where such a risk of externalization may occur. First of all Van den Bergh refers to the fact that such an externalization may occur in case non-pecuniary losses are insufficiently compensated under national law, which may lead to underdeterrence (see Section 7.4.2). Another problem may arise if full scientific proof of a causal link with a certain product defect is required and, for example, proportionate liability is not accepted. The Directive does not cure these problems, since it does not touch upon the issue of causation, nor upon the compensation of non-pecuniary loss, which is explicitly left to the national Member States (Van den Bergh, 1998, p. 145). Moreover, the Directive allows for a financial limit on compensation, which is generally considered inefficient, especially in the case of strict liability (see Faure and Hartlief, 1998). Therefore the Directive in fact increases the risk of cross border externalities, so Van den Bergh $(1998$, p. 145) argues. Finally there is a problem in that the Directive, as we indicated above, does not apply to retailers. Above it was indicated that a state cannot attract industry with lenient product liability legislation for manufacturers, but it could attract retailers by doing so (see Ackerman, 1996, p. 458). The EC Directive does not cure that risk since it does in principle not apply to retailers (see further Van den Bergh, 1998, p. 139).

\subsubsection{Test}

After this analysis of the effectiveness of the European product liability Directive, it seems that the way the product liability Directive is structured makes the case for European harmonization in fact even weaker. If we compare the analysis of the effectiveness of the Directive presented in this section with the criteria for centralization discussed in the previous section we can conclude as follows:

1. The EC product liability Directive is not able to cure the risk of interstate externalities caused by product damage, if there were already such a risk.

2. There is no empirical evidence of a risk that states could attract manufacturers with lenient product liability legislation (the Directive only applying to manufacturers). On the contrary, there might be a risk of a 'race to the top', protecting national victims of product related accidents.

3. The product liability Directive can, given its high reliance on national law, never lead to a 'levelling of the playing field' or a 'harmonization of marketing conditions'.

4. The product liability Directive, which in fact adds an additional layer of complexity to the labyrinth of conflicting standards of liability, does not lead to uniformity or a lowering of transaction costs (compare Ackerman, 1996, p. 454).

Obviously many of these weaknesses are well known to the European Commission itself. Precisely for that reason the product liability Directive provided for a review every five years in fact to proceed towards greater harmonization with a view to establishing a regulatory framework which is as 
comprehensive, coherent, balanced and effective as possible for protecting victims and insuring legal certainty for producers'. ${ }^{56}$

\subsection{PUBLIC CHOICE CONSIDERATIONS}

A question which can obviously not be avoided is whether some of the inefficiencies found with respect to the product liability Directive can be explained on the basis of public choice theory, which pays a lot of attention to the role of interest groups in legislation. ${ }^{57}$ Many scholars have written about the lack of transparency at the European level and the strong lobbying activities in Europe. Several aspects of the European product liability Directive can undoubtedly be considered the result of lobbying.

Interest group considerations might explain why a product liability Directive came into being at all. Since it cannot achieve a 'harmonization of marketing conditions' the Directive might have another reason than the formally stated goal. One important reason might have been the fear of producers in Europe for an American type product liability crisis. As we indicated above (Section 7.3.1) one motive for the Directive was to avoid that some Member States would go too far in their wish to protect 'consumers'. The Directive aims at a balanced approach, so it is stressed many times in the green paper. For that reason the manufacturers are also 'protected' with, for example, some defences, thresholds, relatively short statutes of limitations and the option to impose a financial cap on liability. Since the Directive is clearly mandatory for the areas it covers (meaning that Member States are not allowed to go further in protecting victims in the areas which the Directive covers), the Directive could at least avoid the problem that some Member States might take too far-reaching product liability regimes. But the Directive may also be considered 'defective' in reaching that goal since the areas which could precisely have an increase in liability exposure, for example, the non-pecuniary losses, are not dealt with by the Directive.

Public choice explanations might also have influenced specific features of the Directive. This is obviously the case for the exclusion of primary agricultural products from the scope of the Directive in its original version. Some authors hold that indeed the increased protection of strict liability is only necessary against the increasing risks of modern industrial production. Strict liability for agricultural products would unnecessarily increase the insurance burden (Duintjer Tebbens, 1986, p. 370). This explanation, however, is not convincing. Even if agricultural products are produced industrially, they were still excluded from the scope of the Directive. This means that a consumer will not be able to claim damages against a breeder of veal who has employed artificial hormones or against a grain producer who used dangerous pesticides
(Reich, 1986, p. 143). It is not at all clear why strict liability would not be necessary for those cases. The real reason for the exclusion of primary agricultural products was in fact that European farmers engaged in successful lobbying and convinced the politicians that the Directive's strict liability should not be applicable to them (Reich, 1986, p. 143 and Taschner, p. 259).

Another example constitutes the proposal which was made during the discussion preceding the EC product liability Directive to set up a compensation fund as alternative to product liability. This, however, stood no chance as a result of lobbying by the insurance industry who feared losing business (Van Empel and Ritsema, 1987, p. 53). Therefore Van den Bergh argues that the European product liability Directive is to a large extent to be considered as the result of rent-seeking by industry instead of an instrument to increase economic welfare (Van den Bergh, 1998, p. 151).

The same can be said, moreover, for the general justification for many European Directives, being the 'harmonization of conditions of competition'. This argument is often used by industry in Member States where strict national regulation already applies. In those cases European harmonization has the main effect that artificial barriers to entry are erected. This might also have played a role in the context of the European product liability Directive and it merits careful analysis whether this has not also played a role with respect to the general product safety Directive. One must not forget that in some Member States, especially in the North, such as Germany, the Netherlands and Belgium, a relatively high and elaborate level of product safety existed. If this were the case, industry in those Member States would have an interest to lobby for stringent safety standards at the European level, for the simple reason that they already have to comply with the safety standards nationally. By making their stringent national standards the European norm they can impose these stringent norms also upon their southern competitors. Indeed, as Ogus (1994, p. 198) holds: producers will favour stringent specifications standards if they result in protection against domestic and foreign competitors.

One should, therefore, always be careful with the harmonization of conditions of competition argument, as it is represented in European rhetoric, since it may be in the interest of particular interest groups that conditions of competition are harmonized.

Moreover, one should also be careful with respect to the European product safety Directive in so far as this refers to technical specification standards or codes of good practice, in that standards may, once more, function effectively as barriers to entry. This is a point that certainly merits further empirical investigation.

Finally, in the context of a public choice analysis, one should obviously also point at the interests of the European bureaucracy itself. Until 1985 Europe had done relatively little as far as the harmonization of private law is 
concerned (for obvious reasons of differing legal cultures). It might have been that a European product liability Directive, although it did not fulfil the economic criteria for centralization, might have served the interests of the Brussels bureaucracy to show that Europe could bring about a piece of legislation in an area which is considered important by many lawyers, touches upon manufacturers' interests and is moreover very sensitive in the public opinion. Hence, the fact that the Commission wanted a European product liability Directive may to some extent also simply have been due to the prestige that this Directive would, as one of the first in the area of private law, provide the European Commission.

\subsection{RECENT DEVELOPMENTS}

\subsubsection{Including Primary Agricultural Products}

There was increasing criticism on the exclusion of primary agricultural products after the BSE crisis. One obvious effect of the exclusion of primary agricultural products from the scope of liability under the Directive is that the liability will in fact be passed on to the industrial processor or producer. If, for example, babyfood has been derived from veal which has been treated with hormones, this will not lay a strict liability on the farmer, but on the producer of the finished product (Reich, 1986, p. 143). Of course the cattle breeder might be liable under a fault rule, according to his national tort law (Taschner. 1986, p. 259)

For these reasons the product liability Directive was amended by Directive 1999/34/EC of 10 May 1999 (Official Journal L141, 4 June 1999). The goal of this Directive is to amend the product liability Directive to include defective agricultural products as well. Again, the functioning of the internal market is given as the most important justification:

It is necessary and appropriate in order to achieve the fundamental objectives of increased protection for all consumers and the proper functioning of the internal market to include agricultural products within the scope of Directive 85/374/EEC (see Recital 9).

The idea is that including primary agricultural products within the scope of the product liability Directive would help to restore consumer confidence in the safety of agricultural products. This Directive, including the agricultural products, simply changed the definition of 'product' in the product liability Directive of 1985 and enters into force on the day of its publication in the Official Journal, which was 4 June 1999.
One could argue that with this new Directive, forcing the Member States to apply the product liability regime mandatorily also on agricultural products (whereas before this was optional), one of the criticisms of the Directive (protecting the farmers as a result of lobbying) has disappeared. However, this quick action by the Commission probably indicates more that the sensitivity to European public opinion and the decreasing influence of the agricultural lobby are probably more important reasons for action by the European Commission than the concerns to promote economic welfare.

\subsubsection{Green Paper on Liability for Defective Products}

\section{Objectives of the green paper}

The product liability Directive of 1985 had called for a five year review to analyse the working of the Directive. ${ }^{58}$ This five year review has resulted in a green paper of the Commission which was launched on 28 July 1999 which is addressed to the larger European business and consumer community with two aims:

1. It allows to seek information which will serve to assess its application in the field in view of the experience of those concerned (in particular industry and consumers) and to establish definitely whether it is achieving its objectives;

2. It serves to 'gauge' reaction to a possible revision as regards the most sensitive points of this legislation. 59

The Commission wishes to promote reflection and debate and therefore invites replies provided on facts. Obviously the Commission has indicated guidelines for discussion concerning all of the important topics in the product liability area, such as the existence of financial limits, the 10 year deadline, the burden of proof, the assessment of the insurability of risks, the suppliers' liability and the type of goods and damage covered. Although the green paper clearly states that it does not prejudge the Commission's position on these areas, the fact that a lot of topics which were previously highly criticized are now put on the agenda for possible reform is interesting in the light of the analysis provided in this chapter.

Inefficiencies revisited?

First, a number of features of the product liability Directive which could be criticized from an economic prospective are now openly put on the agenda for possible review (which will obviously not necessarily mean that such a review will take place). Interesting in that respect are inter alia: 
- The fact that the financial limit on liability is put on the agenda for possible reform. There has been debate to increase the option for a ceiling to EUR 140 million, but the question is equally asked whether the existence of financial limits is strictly justified. ${ }^{60}$

- The Commission is also asking the question whether there would be a need to require producers to have insurance cover for risks linked to production. Currently the product liability Directive does not require producers to have any kind of financial cover. Economic analysis indicated that strict liability with insolvency may create inefficiencies, so that this question certainly merits attention.

- The question is also addressed whether the product liability under the Directive should be extended to suppliers. So far, the product liability Directive, with a few extensions, only applied to manufacturers. In that respect the criticism was formulated in the literature that if retailers are excluded from the product liability regime, the Directive can also not be considered as an appropriate means to cure a 'race for the bottom risk' (see above, Section 7.4.3).

It is interesting that some of the issues which were criticized from an economic perspective are now open to possible review. From a normative perspective it can of course be hoped that the European Commission takes the lessons from economic analysis into account.

\section{More transparency?}

Second, there seems to be a trend towards more transparency in the (European) decision-making process, at least on paper. One of the criticisms which could be made on the way that the product liability Directive of 1985 came into being was that apparently many interests have played a role, but that it is not easy to find out what the precise results of the lobbying activities were. The Commission now invites comments on the green paper in the widest possible spirit of transparency:

It was the Commission's intention that the assessment process should be governed by transparency and that producers, consumers, insurers, practitioners and any other sectors concerned should be able to make known their experience and views on implementation and the subsequent development of producers' liability. In this spirit of transparency, the replies will not be confidential and can be made public unless the participants in the consultation process explicitly request otherwise. ${ }^{6}$

Transparency is also an issue as far as the contents of the Directive is concerned. The Commission regrets that today there is no provision in the Directive for any means of making its implementation more transparent. There is, for example, no obligation on producers to keep records of claims against them. The Commission therefore asks whether it would be useful to increase the transparency of the way in which operators apply the rules, especially by identifying the cases involving defective products that are still on the market. ${ }^{62}$

This increasing attention to the transparency issue seems, of course, nice on paper and corresponds with a general concern in Brussels to react to the criticisms concerning the lack of transparency. If the review procedure concerning the Directive were indeed to be truly transparent, this would obviously make lobbying efforts for industry far more costly and might indeed increase the chances that the Directive would be reviewed in a way which corresponds more with public interest.

However, the green paper clearly is still very much concerned with the evolution of product liability law in the US. Differences between European product liability law and US product liability are extensively discussed in the green paper, among others the issue of punitive damages. The Commission concludes:

Seen in this light, the European producer is better off, as the European Directive establishes a uniform and coherent framework of liability, without the most criticized elements of the American system (the role of juries, punitive damages, etc.). ${ }^{63}$

The central goal for a possible revision of the product liability Directive should, therefore, in the words of the Commission, be 'maintaining the balance'. The Commission holds that apparently the European system of product liability constitutes a conciliatory approach, balancing interests of both producers and consumers and the Commission sets as a guideline that this internal balance of the European product liability Directive should be maintained. $^{64}$

Therefore one cannot escape the impression that already this green paper on liability for defective products has largely been issued because of the still growing concern concerning the expanding American product liability regime and the corresponding need to protect European business. This concern to maintain the position of European business in 'the global context' appears clearly from the questions in this respect, which the Commission puts as follows:

Do you think that the Directive weakens the position of European businesses vis à vis their foreign competitors because of the conditions governing liability for defective products?

What are the main reasons for this, and how can it be avoided?

What is the impact of European businesses of exporting products to markets with stricter legislation (or legal practice) such as the United States (in terms of costs, production methods, insurance, level of litigation etc.)? ${ }^{65}$ 
Subsidiarity?

Third, an interesting question obviously arises as to how the Commission considers the task of Europe now that it has (differently from in 1985) to take into account the subsidiarity principle. Does it accept the consequence of 'less Europe' for product liability? The Commission has, on the one hand, as we have just indicated, a lot of attention for the effects of European product liability on the global position of European business, but on the other hand also for the effects of the Directive on intra-community trade. The Commission repeats that the internal market was the goal for the coming into being of the product liability Directive: 'The existence of harmonized legal conditions is intended to make trade easier, since the producer is in the same legal position no matter where his products are distributed' ${ }^{66}$ The Commission, however, agrees that the system of harmonization which is provided in the Directive is 'both incomplete and complementary to any other national producer liability scheme', as we have equally indicated above. However, the Commission argues that the Directive of 1985 should only be seen as an initial step towards establishing a genuine producer liability policy at community level and that the process of reviewing the Directive is in fact to proceed towards greater harmonization. The Commission acknowledges that the objective of total harmonization can only be reached by upholding the present position that no Member State can adopt stricter rules under the Directive. Without spending a lot of words on this, the Commission nevertheless asks the question whether it would be useful to allow each Member State to adopt stricter liability rules, therefore introducing a 'minimum' clause in the Directive. ${ }^{67}$

Although formulated most cautiously, the Commission obviously acknowledges that the Directive in its current form can never reach the goal of total harmonization and therefore at least opens the discussion whether Member States should be allowed to adopt stricter rules. The question whether, in the light of subsidiarity, even more powers to the Member States in this area would be justified is, however, not discussed by the Commission.

\subsubsection{White Paper on Environmental Liability}

In 2000 , the Commission also launched a white paper on environmental liability. ${ }^{68} \mathrm{It}$ is interesting to take a brief look at this white paper on environmental liability to see how the Commission deals with the subsidiarity issue in yet another area of private law. The Commission's approach seems to be far more careful in this area than with respect to product liability where 'total harmonization' is apparently the policy goal. The Commission proposes a strict liability for dangerous activities which are-regulated by EC environment-related law for traditional damage (health and property) contaminated sites and damage to biodiversity. For non-dangerous activities there will be a fault-based liability for damage to biodiversity. Here, the Commission apparently does not propose a European-wide similar environmental liability regime, but links the EC liability regime with existing EC environmental legislation. The idea is that by liability regime with existing EC environmental legislation. The idea is that by be promoted ${ }^{69}$ Obviously, the argument that a community regime for environmental liability should be drafted 'to create a level playing field' in the internal market is again mentioned, but at the same time the Commission states that 'the existence of any problem of competition in the internal market caused by differences in Member States' environmental liability approaches is still unclear'. The Commission specifically focuses its environmental liability regime on damage to biodiversity since most existing Member States' environmental liability regimes do not cover this type of damage. ${ }^{70}$ The approach seems therefore to be rather limited in that it focuses merely on those areas where Member States have apparently not enacted legislation and limits itself to liability resulting from activities regulated under EC environment-related law.

Moreover the subsidiarity issue is expressly addressed, stating that the Commission in fact oniy intervenes to guarantee that the goal of article 174 (1) of the EC treaty (which requires the community policy on the environment to contribute to preserving, protecting and improving the quality of the environment, and to protecting human health) can be achieved. ${ }^{71}$ Interestingly enough the Commission also discusses the possibility of installing a European regime for transboundary damage only. In the literature it has been suggested that if interstate externalities are a reason for centralization, the European Directive should not necessarily cover both local and community-wide pollution. ${ }^{72}$ This idea of a 'transboundary only' regime was rejected, since this could lead to inequalities in treatment of victims in Member States depending on whether they were victims of transboundary or local pollution. ${ }^{73}$ Nevertheless this white paper on environmental liability shows that the Commission now (the white paper was issued on 9 February 2000) seems to be aware of the arguments advanced in economic literature in favour of (de)centralization and at least discusses them.

\subsubsection{Report from the Commission}

As a result of the Green Paper, the European Commission received about a hundred comments from national and European consumer organizations, industry associations and public administrations of Member States. On the basis of all those reactions, the Commission drafted a second report. Indeed, according to article 21 of the Directive, the Commission is supposed to report on the application of the products liability Directive to the council. A first report on the application of the Directive of 13.12.1995 (Com (95) 617) 
simply concluded that there was too little information available on the application of the Directive, so that the Commission did not consider it appropriate to submit any proposals for amendments. On the basis of the aforementioned Green Paper, the Commission published a second report on 31.01.2001 (Com (2000) 893 final).

One of the striking conclusions of this report is that the products liability Directive is seldom applied in practice. The number of product liability cases seems to be low in general; the number of cases which is handled on the basis of the Directive seems to be even lower.

In this report, the Commission also discusses the question as to whether all the issues which were announced for revision in the Green Paper should be reformed or not. The conclusions in that respect are astonishing. After the Commission has discussed all the reactions and suggestions for revision (report, p. 13-27) it only concludes that, at this moment, too little information is available for any reform. Since the Commission judges that too little information is available to draw firm conclusions, it holds that it would be premature to envisage any changes to the current liability system under Directive $85 / 374$.

However, several follow up measures are suggested in the short and medium term. One of these issues is that a reflection should start with 'whether greater harmonization between the different liability systems currently existing would be advisable and, if this was the case, what means would be feasible' (report, p. 30). It is striking that, once more, the Commission only examines whether more harmonization might be advisable, but does not address the more relevant questions; whether the lack of practical importance of the Directive should perhaps lead to less harmonization.

\subsection{CONCLUDING REMARKS}

In this chapter I looked at the question whether product liability and product safety in Europe should be regulated in a decentralized or centralized manner. After a discussion of the economics of product liability and a description of the main features of the product liability and product safety Directives, the economic literature was examined to look at the question whether product safety and product liability should be centralized or decentralized. Europe has traditionally justified harmonization in all kinds of areas, also for product liability, by referring to the traditional argument that conditions of competition should be harmonized to create a level playing field. This argument seems, however, far too general to fit into the economic criteria for centralization. These provide for more balanced answers with respect to the types of subject matter which should be regulated at the centralized or at the decentralized level. These economic criteria were confronted mainly with the way the product liability Directive of 1985 is shaped. The conclusion was that this product liability Directive shows, on the one hand, many inefficiencies and defects and seems also unable to reach its goal of 'harmonization of marketing conditions'. This objective as such has also been criticized on economic grounds since it does not necessarily correspond with economic efficiency.

The main economic argument in favour of centralization, a reduction of transaction costs, may work for product safety, but is far less convincing for instruments of private law, such as product liability. But also as product safety is concerned one should not accept a harmonization of product standards without any critical analysis. If product safety harmonization merely aims at removing useless incompatibilities, such a harmonization seems a useful tool to facilitate international trade. However, the danger always exists that in fact high safety standards are introduced at the European level as mandatory safety regulations to create barriers to entry. Also the various European safety regulation Directives therefore certainly merit further research.

Given the fact that the product liability Directive in its current form cannot reach the objectives it has set and shows various defects and inefficiencies, it may to some extent be explained as the result of lobbying by interest groups. Industrial interest groups probably desired a European product liability Directive which balanced the interests of producers and consumers in order to avoid an 'American' product liability crisis. Moreover, even the Commission argued (in the green paper on liability for defective products and the subsequent Report) that the product liability Directive was only a first step towards harmonization. The own interests of the European bureaucracy of the Commission probably also explains the willingness of the Commission to issue a Directive in the area of liability law, although it should have been clear for the Commission as well that this Directive could never meet the goal of harmonization of marketing conditions.

Product liability in Europe has come to a crucial point now, since the Commission has invited all interested parties via a green paper to comment on the future of the product liability Directive. On paper the Commission calls for more transparency, which may reduce the influence of interest groups. In addition there seems to be, although limited, scope for taking the subsidiarity principles seriously, with respect to product liability. The Commission advanced the option of merely having a basic European product liability regime and giving powers to the Member States to adopt stricter rules (which is not allowed under the product liability Directive today). It would be desirable that at the occasion of this debate on the revisions of the Directive the Commission not only looks at the possibility of minor revisions of the Directive, but reexamines critically the basic question why there needs to be a regulation of product liability at the European level in the first place. Economic literature 
can, as we have tried to show, provide useful and balanced insights to structure a fundamental debate concerning that question.

\section{NOTES}

1. Art. 3 B (2) EC treaty. This formulation has not been changed by the Treaty of Amsterdam, but it has been renumbered to article 5 .

2. For a similar overview of the economic literature see Silva and Cavaliere (2000), pp. 294-8

3. For simple examples see Shavell (1987) and Polinsky (1983, pp. 95-7). See also Silva and Cavaliere (2000, p. 295).

4. A common example is that the potential loss caused by the burning of one's hand through a defective toaster will be much higher for a high quality piano player than for the average economist.

5. This point has been made by Oi (1973) and has been developed by Adams (1987).

6. The reason is, of course, asymmetrical information; see Akerlof (1970).

7. This was especially stressed by Goldberg (1974) in a critique on the work by Oi. For a reaction see Oi (1974).

8. For example the carcinogenic effects of asbestoses.

See Adams (1987, p. 12); Polinsky (1983, p. 99); Shavell (1980, p. 4); for statement is provided by Shavell on pp. 14-17. See also Silva and Cavaliere (2000, p. 295). on pp. 989 .

10. Shavell $(1980, \mathrm{pp} .7$ and $20 ; 1987, \mathrm{pp} .48-51)$. This will often be dependent upon the nature of the activity and the potential harm.

11. Similar points have been made by Hamada (1976, p. 233) and by Epple and Raviv (1978 p. 86). See also Silva and Cavaliere $(2000$, p. 295)

12. For an analysis along these lines see Shavell (1982, pp. 120-32)

13. See the basic article by Akerlof (1970).

14. Priest (1987). The point had also been made by Epstein (1985).

15. See more generally, on this judgement proof problem, Shavell (1986).

6. This point has been made by Landes and Posner (1984), and by Silva and Cavaliere $(2000$, p. 296).

17. This point cannot be elaborated further here. See more generally on the combined use of tort law and regulation Rose-Ackerman (1991; 1992a, pp. 118-31; 1992b).

18. Official Journal, C $241 / 9$ of 14 October, 1976

19. Official Journal, C $114 / 15$ of 7 May, 1979

20. Official Journal, C $127 / 61$ of 21 May, 1979

21. Official Journal, $271 / 3$ of 26 October, 1979.

21. Official Journal, C $271 / 3$ of 26 October, 1979

22. Official Journal, L $210 / 29$ of 7 August, 1985.

23. For the goals of the Directive see also Van Wassenaer van Catwijck (1986a, pp. 793-4).

24. Reich (1996, p. 136). A detailed analysis of the American product liability crisis is provided by Silva and Cavaliere (2000, pp. 299-305).

25. This has, however, recently been changed. This will be discussed in the section dealing with recent developments.

26. See the section in the green paper on 'maintaining the balance' (pp. 18-19), where the Commission especially underlines its fear that Europe should not follow the American example of an expanding product liability.

27. Tiebout (1956). For a discussion of this theory, see Rose-Ackerman, Susan (1992a, pp. 169-70).

28. Although the choice for a particular level regime may not always be related to the quality of the legal system but, for example, to the quality of the court or arbitration system. The latter explains according to Ogus (1999, p: 408), the popularity of English law in choice of law clauses in contracts.

29. As Ogus (1998, p. 407) states, there should be no barriers to the freedom of establistmen and to the movement of capital.
30. Thut is owe of the reasons why Frey and Eichenherger argue in favour of FOCJ: the choice for one legit or instiutional regime slould not be cxclusive; there may be 'overlapping' or one legal or institutional regime a urisdictions depending upon the

1. A major American supported of this 'presumption in favour of decentralization' is Revesz (1997).

2. And might therefore fit into the transaction cost argument, to be discussed below.

33. For a discussion sce Van den Bergh (1998, pp. 136-9).

34. In the words of Rose-Ackerman (1992a, p. 173): "If state and local taws seem designed to protect local business rather than reflect genuine differences in tastes across jurisdiction, the federal government should take a hard look to determine the possible interference with interstate commerce'

35. See article 4 (2) of the Directive $92 / 59$ of 29 June 1992 on general product safety.

36. See for a critical analysis Van den Bergh (1999).

37. For a somewhat related but different argument relating to economic and diseconomics of scale in administration, see Rose-Ackerman (1992a, pp. 165-6).

8. This is one of the arguments made by the Danish scholar Lando (1993) in favour of harmonized private law.

39. It is further developed and criticized by Van den Bergh (1998).

. Compare Rose-Ackerman (1992a, p. 172) who argues that meedictable jurisprudence. reeduce search costs and tends to produce a more stabironmental case, Mendelsohn (1986).

42. That point has expecially been made by Legrand (1997, p. 111).

43. Van den Bergh (1998, pp. 146-7) rightly points at lots of interpretation problems in the European product liability Directive (which we will discuss below) which backs up the conclusion that the transaction costs savings may be small, simply because a full harmonization of rules of private law is apparently difficult to achieve.

44. Almost all authors agree on that point. See Duintjer Tebbens (1986, pp. 373-4; Storm, 1985 . p. 245; Van Wassenaer van Catwijck, 1986b, p. 81).

45. One can, for example, think about the defect notion in article 6 , which inight lead to different interpretations.

46. See, for instance, the different meaning of the "lower threshold' of article 9 in the French and the Dutch version. Another example is that in the English text the producer's liability in called a 'liability without fault" whercas in the Dutch version it is just mentioned as "liahility'. For other examples see Faurc and Vanbuggenhout (1987-1988).

47. Schmidt-Salzer (1986), p. 1104. Article 100 of the EEC treaty indeed gave legislative competence to the community in order to harmonize the different legislations of the Member States. It how hever, heavily debated whether this article 100 was an appropriate basis to Stales. In he This is the title of the article by Storm (1985).

48. This is the the of arte see Van Wassenaer van Catwijck (1986b, pp. 80-81)

50. Which basically means that the victim had a tort based action in which he had to prove a fault of the producer.

51. This is of course more painful for Member States which had no product liability law on 30 July, 1985 than for Member States which already had an elaborated product liability system on that date.

52. Also Cornelis (1987-1988) notices that in comparison with previously existing Belgian Product Liability Law, the victim is worse off under the applicability of the Directive.

53. For an economic analysis of the product liability Directive see also Burrows (1994) and Silva and Cavaliere (2000).

54. One could argue that as soon as a product causes serious injuries it does not provide the safety which a person is entitled to expect and is therefore defective according to article 6 of the Directive.

55. For an economic analysis of liability for defective products see Shavell (1987, pp. 58-60). For an analysis of the notion of defect in the Directive see Finsinger and Simon (1989). 
56. Green paper on liability for defective products, p. 11.

57. See for a discussion of the harmonization efforts from a public choice perspective. Van den Bergh (1998, pp. 148-51).

58. See article 21 of the product liability Directive which stat es 'Every live years tire Commission stall present a report to the Council on the application of this Directive, and, if necessaty, shall submit appropriate proposals to it'

59. See green paper on liability for defective products, p. 2

60. Greei paper on liability for defective products, p. 26

61. Green paper on liability for defective products, p. 8.

62. Green paper on liability for defective products $\mathrm{pp} .28-9$

63. Green paper on liability for defective products, p. 13

64. Green paper on liability for defective products, pp. 18-20.

65. Green paper on liability for defective products, p. 14

66. Green paper on liability for defective products, p. 10.

67. See green paper on hability for defective products, pp. 11-12

68. Com (2000) 66 final of 9 February 2000

69. White paper on environmental liability, p. 12.

70. White paper on environmental liability, pp. 12-13.

71. White paper on environmental liability, p. 27

72. Van den Bergh (1999, p. 10) suggested that a distinction should be made between regional and interstate pollution.

3. White paper on environmental liability, pp. 25-6.

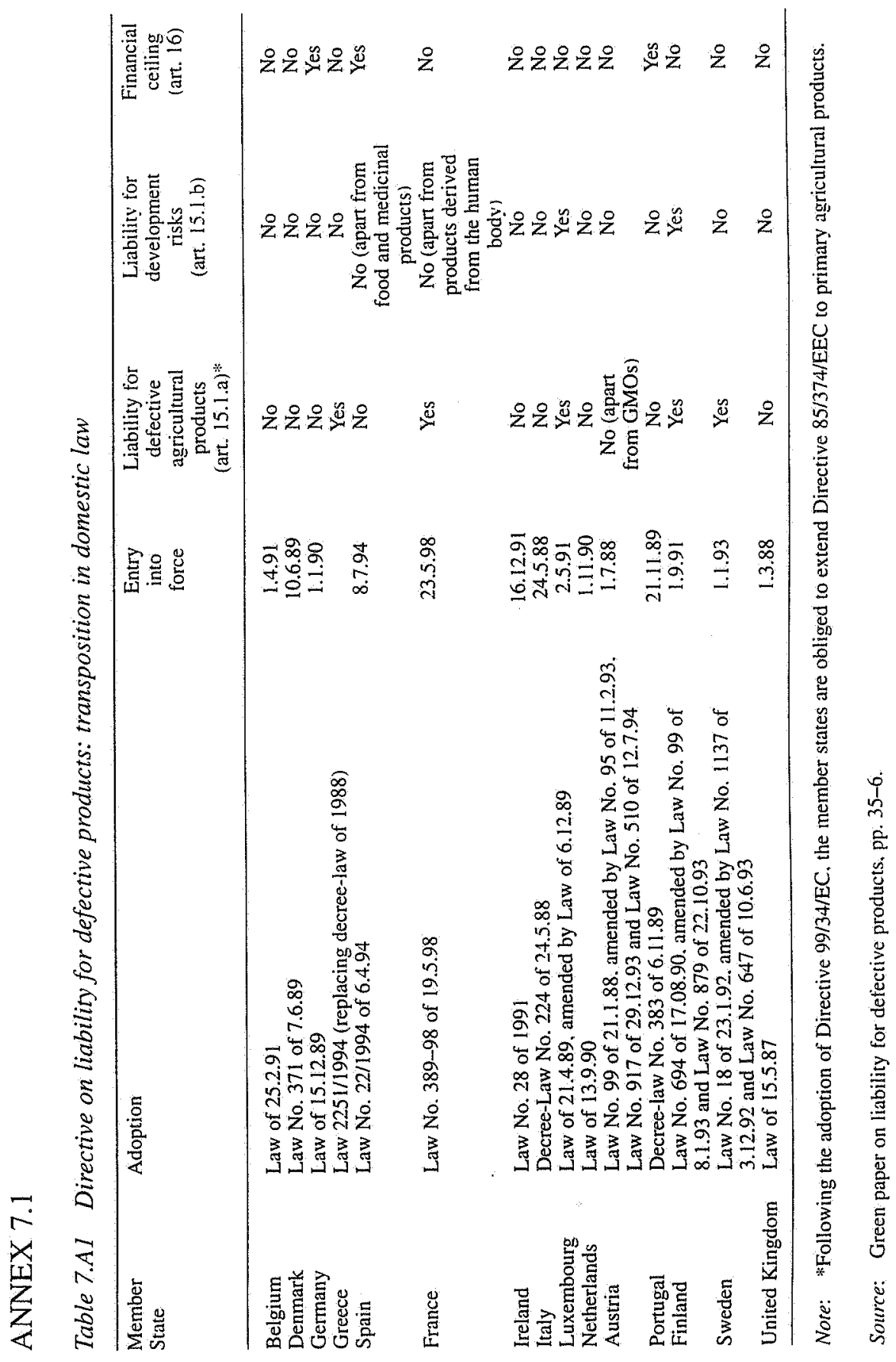




\section{REFERENCES}

Ackerman, R.M. (1996), 'Tort law and federalism: whatever happened to devolution?', Yale Law and Policy Review, (Symposium Issue), 429-63.

Adams, M. (1987), 'Wohltat oder Plage - eine ökonomische Analyse', Betriehsherater. Beilage 20/1987 zu Heft 31/1987, 5-10.

Akerlof, G. (1970), 'The market for "lemons": quality uncertainty and the market mechanism', Quarterly Journal of Economics, 488.

Buchanan, J. (1970), 'In defense of caveat emptor', University of Chicago Law Review', 64-73.

Burrows, P. (1994), 'Products liability and the control of product risk in the European Community', Oxford Review of Econonic Policy, 10, 68-83.

Casella, A. and B. Frey (1992), 'Federalism and clubs. Towards an economic theory of overiapping political jurisdiction', European Economic Review, 36, 639.

Coase, R.H. (1960), 'The problem of social cost', Journal of Law and Economics, 3 $1-44$.

Cornelis, L. (1987-1988), 'Aansprakelijkheid voor gevaarlijke producten', Rechtskundig Weekblad, 51, 1139-59.

Duintjer Tebbens, H. (1986), 'De Europese richtlijn produktaansprakelijkheid', Nederlands Juristenblad, 369-74.

Epple, D. and A. Raviv (1978), 'Product safety, liability rules, market structure, and imperfect information', American Economic Review, 86.

Epstein, R. (1985), 'Product liability as an insurance market', Journal of Legal Studies, $650-52$.

Esty, D. (1996), 'Revitalizing environmental federalism', Michigan Law Review, 95, 625.

Faure, M. (1998), Aktuelle Regulierungspraxis bei Heilwesenschäden in Europa mit Ausblick auf die EG-Rechtscharmonisierung, Detmold: Ecclesia.

Faure, M. and W. Vanbuggenhout (1987-1988) 'Produktaansprakelijkheid. De Europese richtlijn: harmonisatie en consumentenbescherming?', Rechtskundig Weekblad, 51, 1-14 and 33-49.

Faure, M. and T. Hartlief (1998), 'Remedies for expanding liability', Oxford Journal of Legal Studies, 18, 681-706.

Faure, M. and T. Hartlief (1996), 'Towards an expanding enterprise liability in Europe'? How to analyse the scope of liability of industrial operators and their insurers', Maastricht Journal of European and Comparative Law, 5, 235-70.

Finsinger, J. and J. Simon (1989), 'An Economic assessment of the EC Product Liability Directive and the Product Liability Law of the Federal Republic of Germany', in Michael Faure and Roger Van den Bergh (eds), Essays in Law and Economics, Antwerp: Maklu, pp. 185-214.

Frey, B. (1994), 'Direct democracy: politico-economic lessons from Switzerland', American Economic Review, 84, 338-42.

Frey, B. (1996), 'FOCJ: competitive governments for Europe', International review of Law and Economics, 16, 315-27.

Frey, B. and R. Eichenberger (1996), 'To harmonize or to compete? That's not the question', Journal of Public Economics, 60, 335-49.

Goldberg, V. (1974), 'The economics of product safety and imperfect information', Bell Journal of Economics, 5, 683-8.

Hamada, K. (1976), 'Liability tules and income distribution in product liability', American Economic Review, 66, 228-34.
Inman, R. and D. Rubinfeld (1994), 'The EMU and fiscal policy in the new European Community: an issue for economic federalism', International Review of Law and Economics, 14, 147-61.

Kimber, C. (1995), 'A comparison of environmental federalism in the United States and the European Union', Maryland Law Review, 54, 321.

Kirchgässner, G. and W. Pommerehne (1993), 'Tax harmonization and tax competition in the European Community: lessons from Switzerland; paper presented at the Cost Mecting in Luzern, November 1993.

Kirstein, R. and A.R. Neunzig (1999), "Internationale Zuständigkeit von Gerichten und dic Anerkennung ausländischer Urteile' in K.E. Schenk, D. Schmidichen, E. Strei and V. Vauberg (eds), Jahrbuch für neue politische ökonomie, globalisierung und Rechtsorthung, Mohr: Siebeck, p. 345-68.

Krämer, L. (1986), 'EEC Consumer Law', in Droit et Consommation, Brussels, pp. 274-5.

Landes, W. and R. Posner (1984), 'Tort law as a regulatory regime for catastrophic personal injuries', Joumal of Legal Studies, 13, 421-2.

Lando, O. (1993), 'Die Regeln des Europäischen Vertragsrecht', in Peter-Christian Müller-Graff (ed.), Gemeinsames Privatrecht in der Europäischen Gemeinschaft, $473-4$.

Legrand, P. (1997), 'The impossibility of legal transplants', Maastricht Journal of European and Comparative Law, 4, 111-24.

McKean, R. (1970a), 'Products liability: trends and implications', University of Chicago Law Review, 3-63.

McKean, R. (1970b), 'Products liability: implications of some changing property rights', Quarterly Journal of Economics, 611-26.

Mendelsohn, R. (1986), 'Regulating heterogeneous emissions', Journal of Environmental Economics and Management, 13, 301.

Oates, W. (1972), Fiscal Federalism.

Oates, W. and R. Schwab (1988), 'Economic competition among jurisdiction: efficiency enhancing or distortion inducing?', Journal of Public Economics, 35, 333-54.

Ogus, A. (1994), Regulation, Legal Form and Economic Theory, Oxford: Clarendon Press.

Ogus, A. (1999), 'Competition between national legal systems. A contribution of economic analysis to comparative law', The International and Comparative Law Quarterly, 48, 405-18.

Oi, W. (1973), 'The economics of product safety', Bell Journal of Economics, 3, 3-28.

Oi, W. (1974), 'The economics of product safety: a rejoinder', Bell Journal of Economics, 689-95.

Polinsky, A.M. (1983), An Introduction to Law and Economics, Boston: Little, Brown. Polinsky, M. and W. Rogerson (1983), 'Products liability, consumer misperceptions, and market power', Bell Joumal of Economics, 581-9.

Priest, G. (1987), 'The current insurance crisis and modern tort law', The Yale Law Journal, 96, 1521-90.

Reich, N. (1986), 'Product safety and product liability', Joumal of Consumer Policy, $137 \mathrm{ff}$.

Revesz, R. (1997), 'Federalism and environmental regulation: lessons for the European Union and the international community', Virginia Law Review, 83, 1331-46.

Rose-Ackerman, S. (1991), 'Regulation and the law of torts', American Economic Review, Papers and Proceedings, 54-8. 
Rose-Ackerman, S. (1992a), Rethinking the Progressive Agenda. The Reform of the American Regulatory State, New York: Free Press.

Rose-Ackerman, S. (1992b), 'Environmental Liability Law', in T.H. Tietenherg (cd.), Innovation in Environmental Policy, Economic and Legal Aspects of Recemt Developments in Environmental Enforcement and Liability, Brookfield: Elgon, pp. $223-43$.

Rose-Ackerman, S. (1995), Controlling Envirommentul Polic v. 7he limits of pullic law in Germany and the United States, New Haven: Yale University Press.

Schmidt-Salzer (1986), 'Die E.G. Richtlinie Produkt-Haftung', Betrichs-Bcrater. pp. $1103-11$

Schwartz, G.T. (1996), 'Considering the proper federal role in American tort law', Arizona Law Review, 38, 917-51.

Shavell, S. (1980), 'Strict liability versus negligence', Journal of Legal Studies, $1-25$.

Shavell, S. (1982), 'On liability and insurance', Joumal of Economics, 120-32.

Shavell, S. (1984a), 'Liability for harm versus regulation of safety', Joumal of Legal Studies, 357-74

Shavell, S. (1984b), 'A model of the optimal use of liability and safety regulation', The' Rand Joumal of Economics, 271-80.

Shavell, S. (1985), "Criminal law and the optimal use of non-monetary sanctions as a deterrent', Columbia Law Review, 1232-62.

Shavell, S. (1986), 'The judgement proof problem', International Review' of Law' and Economics, 43-58

Shavell, S. (1987), An Economic Analysis of Accident Law, Cambridge, MA: Harvard University Press.

Silva, F and A. Cavaliere (2000), 'The Economic Impact of Product Liability: Lessons from the US and the EU Experience', in G. Galli and J. Pelkmans (eds), Regulatory Reform and Competitiveness in Europe, I., Horizontal Issues, Cheltenham: Edward Elgar, pp. 292-323.

Skogh, G. (1982), 'Public insurance and accident prevention', International Reriew' of Law and Economics, 67-80.

Storm, P. (1985), 'Een gebrekkig product', TVVS, 241-6.

Taschner, H. (1986), 'La future responsabilité du fait des produits défecteux dans la communauté européenne, Revue du Marché Commun, 257.

Tiebout, C. (1956), 'A pure theory of local expenditures', Journal of Political ". Economy, 64, 416-24.

Trebilcock, M. and R. Howse (1998), 'Trade liberation and regulatory diversity. Reconciling competitive markets with competitive politics', European Journal of Law and Economics, 6, 5-37.

Van den Bergh, R. (1994), 'The subsidiarity principle in European community law', Maastricht Journal of European and Comparative Law, 4, 337-66.

Van den Bergh, R. (1998), 'Subsidiarity as an economic demarcation principle and the emergence of European private law', Maastricht Journal of European and Comparative Law, 2, 129-52.

Van den Bergh, R. (1999), 'Economics in a legal straight-jacket: the difficult reception of economic analysis in European law', paper presented at the workshop Empirical Research and Legal Realism. Setting the agenda, Haifa, 6-9 June 1999.

Van den Bergh, R., 'Competition law and competition in Europe after 1992. Will free riders become the heroes of the internal market?', unpublished manuscript.

Van Empel, M. and Ritsema, H. (1987), Aansprakelijkheid voor prodicten. Deventer, Kluwer
Van Wassenaer van Catwijck, A.J.O. (1986a), 'Products liability in Europe', The American Journal of Comparative Law, 793-4.

Van Wassenaer van Catwijck, A.J.O. (1986b), Produktaansprakelijkheid, in Serie Praktijkhaudleidingen, Zwolle: Tjeenk Willink.

Veljanovski, C.G. (1981), 'The Economic Theory of Tort Liability - Toward a Corrective Justice Approach', in Paul Burrows and Cento Veljanovski (eds), The liconomic Apmroceh to Law, London: Butlerworth.

Viscusi, W.K. (1988), 'Product liability and regulation: establishing the apprepriate institutional division of labour', American Economic Review, 3(0)-304.

Vogal, D. (1995), Trading Up, Consumer and Environmental Regulation in a Global Economy, Cambridge: Harvard University Press.

Wituman, D. (1977), 'Prior regulation versus post liability: the choice between input and output monitoring', Journal of Legal Studies, 193-211. 